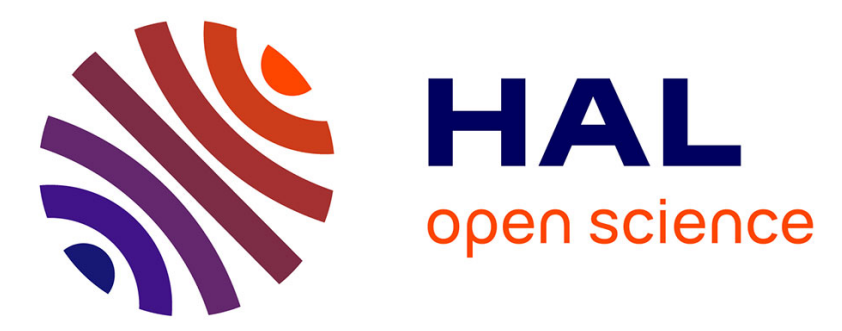

\title{
The determinants of cleaner energy innovations of the world's largest firms: the impact of firm learning and knowledge capital
}

Patricia Laurens, Christian Le Bas, Stéphane Lhuillery, Antoine Schoen

\section{To cite this version:}

Patricia Laurens, Christian Le Bas, Stéphane Lhuillery, Antoine Schoen. The determinants of cleaner energy innovations of the world's largest firms: the impact of firm learning and knowledge capital. Economics of Innovation and New Technology, 2017, 26 (4), pp.311-333. 10.1080/10438599.2016.1193940 . hal-01775110

\author{
HAL Id: hal-01775110 \\ https://hal.science/hal-01775110
}

Submitted on 27 Apr 2018

HAL is a multi-disciplinary open access archive for the deposit and dissemination of scientific research documents, whether they are published or not. The documents may come from teaching and research institutions in France or abroad, or from public or private research centers.
L'archive ouverte pluridisciplinaire HAL, est destinée au dépôt et à la diffusion de documents scientifiques de niveau recherche, publiés ou non, émanant des établissements d'enseignement et de recherche français ou étrangers, des laboratoires publics ou privés. 


\section{The determinants of cleaner energy innovations of the world's largest firms: the impact of firm learning and knowledge capital ${ }^{1}$}

Patricia Laurens (patricia.laurens@esiee.fr)

Université Paris-Est, CNRS - LISIS - IFRIS, 2, bd Blaise Pascal, 93160 NOISY LE GRAND

(France) Tel + 33 (0)1 45926634

Christian Le Bas corresponding author (clebas@univ-catholyon.fr)

ESDES - School of Management - Catholic University of Lyon. 23 Place Carnot, 69002 Lyon- 69002 Lyon (France). Tel: 33681813997

Stéphane Lhuillery (stephane.lhuillery@icn-groupe.fr)

ICN Business School, 3 place Edouard Branly, 57070 Metz Technopole France \& BETA (UMR-CNRS 7522), University of Nancy) Tel $+33(0) 387563776$

Antoine Schoen (a.schoen@esiee.fr)

Université Paris-Est, ESIEE - LISIS - IFRIS, 2, bd Blaise Pascal, 93160 NOISY LE GRAND (France)

Tel + 33(0)145926099

\section{Abstract}

In this paper, we address the determinants of clean energy inventions by 946 large firms. We use a new set of large firms 'patent portfolios and we broaden and deepen existing literature on this issue in two main ways: first, we conduct our study directly at the firm level and not at the industry or national levels and second, we do not focus on a single industry but encompass all industrial sectors. Drawing on firm (internal and external) knowledge and knowledge accumulation, we show there is a robust positive association between the (past) knowledge accumulated capital related to clean technologies and the number of inventions produced in that field, even after controlling for industry and nation fixed effects and other factors. The same relation works for (past) knowledge accumulated capital in other (non-clean) technologies. However, the relation's impact on the number of clean inventions produced is much lower. The magnitudes of our coefficient are in line with that obtained previously on firms in the auto-industry or at the sectoral level.

Key words: clean invention, dirty invention, knowledge capital, firms, learning

\footnotetext{
1 A first draft of the article was set out at the international conference "Gouvernance of a Complex World 2014", 18-20 Jun 2014 Torino (Italy). We warmly thank our discussant Cédric Gossart for his valuable comments.
} 


\section{Introduction}

The global climate crisis is a major concern for economists working on environmental and technological innovations. The crisis makes it clear that clean public R\&D investment, procurement or infrastructure cannot achieve a drastic reduction of greenhouse gas emissions and that a real commitment by the private sector for producing new clean energy technology or for adopting new cleaner equipment is needed (Veugelers, 2012) ${ }^{2}$. Transition to a low carbon economy or/and a more sustainable economy requires a more intensive rhythm of industrial innovations in the fields of clean energy technologies. The production, development and diffusion of environmental innovations (EI thereafter) are critical for achieving sustainable growth. It is also acknowledged that private industrial firms will not achieve this transition without sufficient incentives. Moreover, as emphasized in a significant portion of the literature, such a transition necessarily implies interactions between private and public sectors (see in particular Marin and Mazzanti, 2009: Nill and Kemp, 2009). Consequently, a public policy based on a portfolio of incentives is justified. These incentives would include carbon taxes and academic research subsidies for encouraging R\&D directed to environmental technologies (see among others Acemoglu et al., 2012). Innovation is a key element behind the achievement of environmental and economic performance (Gilli et al., 2013).

One motivation for understanding the drivers of clean energy innovations is that the environmental impact of the economic activity is greatly affected by the rate and direction of technological change (Jaffe et al., 2000). In this paper, we focus our attention on a firm's strategies for innovating in technologies related to greenhouse gas emission mitigation. We have minimal knowledge regarding the volume of innovations that are needed to implement cleaner energy systems, and we know less about their determinants. Consequently, echoing the work by Jaffe et al. (2000), we use patent data to address the issue of the determinants of the rate and direction of technological progress at the microeconomic level, focusing on the role of knowledge spillovers and accumulation.

It is important to rigorously define what green innovations mean ${ }^{3}$. Following Kemp and Foxon (2007), we define environmental or green innovation as the "production, assimilation or exploitation of product, production process, service or management or business methods that is novel to the organisation (developing or adopting it) and which results, throughout its life cycle, in a reduction of environmental risk, pollution and other negative impacts of resources use (including energy use) compared to relevant alternatives". Often technological, organisational and marketing innovations are implemented considered all together (Horbach et al., 2011). Furthermore, incremental strategies rather than more radical strategies have predominated until now. It is generally considered as insufficient when we examine long-term economic and environmental goals (Gilli et al., 2013) ${ }^{4}$.

In the past the literature mainly focused on industry specific determinants of clean innovation, following the seminal analysis by Poter and Van Linde (1995). Nowadays firm's level variables emerge as important factors (De Marchi, 2012). Firm innovation resources are now considered more relevant than industry level factors to explain green innovation intensity (De Marchi et al, 2015). If we adopt a broader perspective, it is relevant to start with the idea that three main effects account for a firm's adoption of clean innovation: 1) the demand side effect (often with energy price as a proxy, see for instance Verdolini and Galeotti, 2011), 2) the supply side effect generated by technological opportunities that govern the cost of researching and developing new technologies, 3) the policy side effect. By this, we mean policy that directly affects economic agent behaviour through strict regulation

\footnotetext{
${ }^{2}$ We define clean energy technology later in the paper.

${ }^{3}$ During the last ten years, cleantech and greentech are most often used as synonyms. However cleantech has historically been differentiated from greentech by its origins in the venture capital investment community. It used to define a business sector that included significant and high growth industries such as solar, wind, water purification, and biofuels. This was in contrast to greentech, an older term representing the highly regulatory driven, "end-of-pipe" technology of the past with limited opportunity for attractive returns, Cleantech is driven by economic market, therefore offering a greater financial upside.

${ }^{4}$ Regulation is a crucial driver of eco-aiming to correct negative externalities due to pollution.
} 


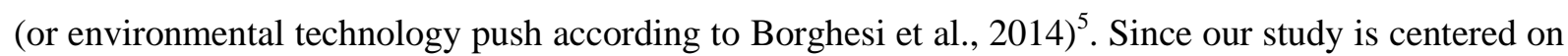
top multinational $R \& D$ investors with $R \& D$ facilities and markets worldwide, we focus on technological opportunities, measured by the firm's stock of technological knowledge. Specifically, we consider the creation of clean inventions (at least those for which a patent is applied for) by firms and do not pay attention to the adoption of clean innovation by firms. We are particularly interested in one specific class of green innovations: those in the energy field dedicated to mitigating global warming and reducing GHG emissions (Veefkind et al., 2012). Consequently, we define clean inventions or clean technologies (cleantech) as coming under the umbrella of greentech inventions, and specifically which contribute to the mitigation of global warming and reductions in GHG. In this paper we basically address clean inventions. ${ }^{6}$

Whereas CIS data provide a great deal of information about green innovations in general and enable us to assess the firm's propensity to implement green innovations, they do not provide many details on clean inventions. In contrast, we propose to use patent data in order to obtain a richer information. We can retrieve clean energy invention information because of the work performed by the European Patent Office, with the objective of tagging inventions patented in climate change mitigation technologies and can identify in the Patstat patent database the patent portfolios of each firm based on a consolidated firm perimeter. We are thus able to explain not only a firm's propensity to implement clean energy innovations, but also the scale at which it invests in clean technologies through the quantity of patents it applies for. Thanks to the patent data, we can further compute the pool of knowledge produced by other companies that is likely to help the firm to invent in green energy. Finally, the firm's past experience or its surrounding knowledge pool can be disentangled between clean and non-clean technologies in order to control overlaps between the two categories. The present article thus proposes a cross-section econometric model where the cleantech inventions done by 946 worldwide top R\&D investors over the 2003-2005 period are driven by the experience firms accumulated in clean and dirty technologies between 1986 and 2002, as well as, clean and dirty spillovers. The paper proceeds in the following manner. We first provide a brief review of the literature in section 1 and main theoretical frameworks dedicated to explaining the main drivers of clean inventions. We provide more details on our research question in section 2 where we pose our hypotheses. Section 3 delineates our data set, the sampling of large worldwide firms, our variables, and the econometric method implemented. Section 4 presents and discusses our results. A final section concludes.

\section{Literature background}

The literature largely reflects a widespread belief that climate change can be achieved through the production of new technologies and its adoption by users. Three main determinants are considered ${ }^{7}$ : relative prices, environmental standards and innovation policies.

The first determinant considers the substitution rate between existing dirty $^{8}$ and clean technologies. Substitution relies on the relative price between the two technologies. Hence, many scholars put forth energy price as a main driver of directed technical change (for instance: Crabb and Johnson, 2010; Hassler et al., 2012; Newell et al. 1999; Popp, 2002 and Aghion et al., 2015). A cheap dirty energy technology is more likely to maintain its dominance over time. When relative prices are not persuasive for investors, taxes on the use of dirty technologies or subsidies for cleaner technologies can be

\footnotetext{
${ }^{5}$ It is acknowledged that environmental innovation oriented policies positively affect the rate of technological change in the field of green technologies (see Johnston et al., 2010).

${ }^{6}$ We consider the terms 'green-innovation' and 'environmental innovation' equivalent. However, we explicitly differentiate the term clean innovation, i.e., climate-friendly innovation, from all other green innovations.

${ }^{7}$ Other sources and drivers of innovation play a role in this process as organisational arrangements (Dosi, 1997

${ }^{8}$ Here when we speak about dirty technology, we mean in fact not clean technology. Many authors put the word dirty in brackets in order to show that dirty technology may not augment the negative impact on climate change..
} 
considered to accelerate substitution toward cleaner solutions. Such changes in relative prices have not only a static influence with the better use of existing energy-efficiency technologies but also an induced increase in demand. Moreover market size for cleaner products and processes are likely to influence technological opportunities and thus prompt investments in future clean technologies (e.g. Aghion et al., 2015). Scholars therefore usually acknowledge that complementary tools are likely to be implemented to obtain an optimal policy mix able to manage static and dynamic aspects. This policy mix encompasses mainly 'regulation' policy and innovation policy (Porter and van der Linde, 1995; Cowan and Kline, 1996; Jaffe and Newell, 2002; Acemoglu et al., 2012; Veugelers, 2012).

For instance, Porter's hypothesis (Porter and van der Linde, 1995) advocates that a set of more stringent environmental regulations (e.g. more stringent performance and technology-based standards or tradable permits) can also induce efficiency by encouraging firms to develop new clean process innovations and then reduce their production costs. The first issue with this is that higher efficiency is achieved when overcompensating for both the compliance costs linked to environmental regulations and the innovation costs. The second issue is that a firm may be compliant with incremental changes and the adoption of resources available on market, meaning that the link between regulatory compliance and innovation and especially radical innovation is not systematic. Finally, regulation instruments such as standards are also likely to limit rather than trigger innovation (Jaffe et al., 2002): once the technology standard is no longer binding, firms do not further look for innovation. Worse, when firms anticipate that a government will increase cost and regulation for dirty technologies in the future, they may implement innovation in old technologies to exploit them more rapidly and more efficiently before their cost increases too much (Sinn, 2008). Despite the criticisms (Jaffe et 1997; Jaffe et al., 2002; Wagner, 2003; Ambec et al., 2013) and the skepticism on the Porter and Van der Linde's insights, many scholars have tested the influence of regulations on filed clean-tech inventions ${ }^{9}$. Firm level studies largely confirmed that more stringent environmental policies induce more clean innovations (e.g. Lanjouw and Mody, 1996; Jaffe et al., 2002; Rehfeld et al., 2007; Popp et al., 2009; Calel, and Dechezlepretre, 2012; Kesidou and Demirel, 2012; Carrión-Flores et al., 2013; Borghesi et al., 2014) even if some discrepancies have been found at the industry level (e.g. Jaffe and Palmer, 1997).

Finally, the literature usually insists on the role of innovation policies complementing market-based instruments and regulation tools. Specific funds, grants, subsidies and R\&D tax credit can provide direct incentives toward the production of new clean products or processes and their diffusion. Lowering production costs but also adoption costs of clean innovation by direct or indirect policies should help firms to create and adopt new products and processes more quickly and comprehensively. Empirical studies have highlighted the positive role of innovation policies on clean-environmental innovation even if the results can be nuanced (Brouhle et al, 2013). The results can be mitigated when $R \& D$ is taken as a proxy for environmental innovation or when the impact of $R \& D$, influenced by innovation policies, is compared with the impact of regulation policies. In this type of literature (see Ghisetti Pontoni, 2015), clean-innovation policies are however usually identified only at national level not at the firm level (e.g. Popp, 2002). At the firm level, environmental innovation policies can be mixed with other innovations policies, preventing clear conclusions. Similarly, as already mentioned, $\mathrm{R} \& \mathrm{D}$ efforts may not be a good proxy for R\&D efforts in clean-tech fields and make studies choosing patents more interesting (see Wagner, 2008). Furthermore, the identification of the role of innovation policies is also challenged since the literature to date has not implemented treatment or multiple models to compare treated and non-treated firms when data on non-treated firms are available (see Brouhle et al., 2015). Innovation policies addressed in the literature usually focus on industrial policy and very little on research policy: the role of academic laboratories and their ability to contribute to the pool of knowledge that firms can absorb, and thus their indirect role in environmental innovation, is usually overlooked. Few econometric papers are available at the firm level for multiple industries. On the one hand, some positive roles are identified (e.g. Cainelli et al., 2012). On the other hand, public research organizations are not found to be influential when $\mathrm{CO} 2$ reduction is considered (Borghesi et

\footnotetext{
${ }^{9}$ Many authors also take R\&D expenditure as a proxy of innovation efforts in clean-tech (see Jaffe et al., 2002 for a survey) despite the inability to observe the share of R\&D budgets dedicated to clean-tech fields.
} 
al, 2014). An important caveat in the empirical literature focused on market based determinants and policy tools, is that it does not comprehensively consider knowledge sourcing activities implemented by firms in order to be able to achieve innovation.

More generally, the academic literature on environmental innovation pays relatively little attention to the dynamic of knowledge at the firm level. A specific subset of authors have acknowledged the difficulties for ecological policy makers to shape and identify the best opportunities and arbitrage over the long run, from a private and social point of view (Jaffe and Newell, 2002; Veugelers, 2012). Knowledge accumulation is considered as a problem that may drive firms (and the economy) along sub-optimal clean technologies trajectories where switching costs may hamper the development of the cleanest choices, and either maintain the firm on its old trajectory (Unruh, 2000) or locking the firm into a sub-optimal new technology trajectory (Klitkou et al., 2015).

The main aim of the paper is to propose a general inquiry into the existence, the importance and the past-path dependence of knowledge accumulation, including spillovers at the firm level. Insights of path dependence of environmental innovation are available but only at the national level (Popp, 2002; Popp et al., 2011), at the industry level (Stucki and Woerter, 2012) or on a single industry (Aghion et al., 2015). In contrast we will work on a large sample of firms from many countries and sectors. A second task is to characterize the different flows of knowledge that firms are able to draw on. In this respect, some empirical contributions have already identified the role of spillovers (Lanjouw and Mody, 1996; Stucki and Woerter, 2012; Piscitello et al.; 2012; Aghion et al., 2015). In this literature, knowledge accumulation is however rather based on geographical spillovers (see Lanjouw and Mody, 1996; Piscitello et al.; 2012; Verdolini, E., Galeotti, M., 2011; Cainelli et al., 2012; Corradini et al. 2014 and 2015; Peters et al., 2012). Even if local, national or international spillovers and policies matter, an even more critical dimension for environmental innovation and environmental innovation policies is that clean technologies inventions can heavily depend on a set of know-how in dirty technologies (as in Stucki and Woerter, 2012; Aghion et al., 2015). Individual level and multi-industry studies are still missing when the role of inter-sectoral spillovers is at stake.

The literature we reviewed does not examine the knowledge factors driving the amount of cleaner innovations at the firm level, especially regarding path dependence and intra and inter-tech spillovers occurring in different sectors. In the following sections, we propose to fill this gap by providing more general findings from a sample of large firms from diverse sectors and nations, distinguishing clean innovations from dirty innovations. Our contribution is the first to address clean energy innovation determinants by delineating the scale, the variety and the knowledge drivers of clean energy innovations for a large diversified sample of worldwide leading firms top R\&D investors. In order to simplify the presentation we simply use the term large firms to designate them ${ }^{10}$.

\section{Framework and hypotheses}

The volume of inventions achieved is linked to the amount of resources invested in this specialised activity. The knowledge production function (Griliches, 1995) coherently delineates this relation. A strong knowledge base including R\&D capacity (Nelson and Winter, 1982) and a well-trained workforce (Archibugi and Lundvall, 2001) are critical to successful innovation. A firm's capabilities to achieve technological changes are of key importance and are correlated to the strength of its knowledge base (Nelson and Winter, 1982). This strength tends to define knowledge cumulativeness as a very important property of the process of innovation production (Malerba and Orsegino, 1999). In short, this puts forward the idea that current knowledge for innovation today provides the matrix for the knowledge for the innovation of tomorrow. As a consequence, one of the most important factors of the probability of a firm to undertake innovation in cleaner technology relies on the knowledge base possessed by a firm in this technological field.

\footnotetext{
${ }^{10}$ As previously done by Pavitt and Patel (1991).
} 
The role of external knowledge is also critical. Few firms can rely exclusively on their own internal knowledge accumulated over time, even when it accumulates knowledge effectively. A firm searches for, finds, and uses external knowledge through market transactions (for instance, the practices of licensing in, or know-how acquired through the hiring of workers), open innovation practices and relevant non-market interactions (spillovers). Creating a strong internal knowledge base is a precondition for detecting and absorption of any piece of external knowledge produced by competitors, suppliers, clients or public research organizations (Cohen and Levinthal, 1990). Innovative activity is particularly dependent upon knowledge that can be accumulated through experience in the industry (Kepler, 1996). The learning process turns out to be more complicated in the energy sector. For instance Mowery et al. (2010) have shown in the sector of energy technologies that innovator-developers are not often adopter-users.

With respect to technological learning, our approach is directly related to three properties identified by the literature. Technological change is past dependent. Through past dependent learning a firm knows how to implement new internal organisations for knowledge creation. Firms use embedded routines and consequently are less likely to make errors. This means they can produce knowledge with lower costs. This knowledge is likely to have a larger impact than knowledge that emerges through a trialand-error process of a broad temporal search (Nerkar, 2003). Technological change is also pathdependent. Firms are reacting agents that can succeed in their new knowledge production when they are not locked into a particular technological knowledge base. There are constrained by their past decisions but remain creative, and are able to generate new knowledge by means of both learning and intentional innovative strategies. Doing so, they can redirect the process of knowledge accumulation toward new emergent technologies (Teece, 2007; Antonelli, 2011). The variety of knowledge enables firms to escape inertia. Through repeated re-combinations of different pieces of knowledge, individuals can discover an invention (Fleming and Szigety, 2006). The more an agent recombines knowledge, the higher the number of possible inventions. The literature also provides arguments and evidence where crossing bits of knowledge from diverse technological fields is likely to lead to radical innovation (See Zahra and George, 2002; Taylor and Greve, 2006).

These properties are critical for firms with steady and persistent technological production (firms from Schumpeter Mark II model according to Malerba and Orsenigo (1997)). At some point in time, a firm that is specialized in a set of technologies may decide to invest in a new area of knowledge (for instance green energy technologies). When a firm begins to modify its knowledge base for investing substantially in another technology, it diversifies its technological competences. The profile of firm technological competences is likely to evolve slowly over time: the knowledge production process and fields of specialization depend on past inventive activities (past dependence) while diversification changes are rather seldom and somewhat incremental (path-dependence).

A firm's decision to invest in the knowledge related to green energy technologies therefore reflects process technological specialization and/or diversification. These two processes depend on the firm's initial and past levels of specialization. Considering that the variety and specialization of knowledge can be reduced to a set of two types of technologies (clean energy technology and other technologies labelled as 'dirty' in Aghion et al, 2015 or Acemoglu et al, 2014), the commitment of firms to green energy technologies will depend on previous commitments to these technologies. Past accumulated knowledge in dirty technologies is also likely to shape present invention activity in the area, and vice versa. Firms have to manage learning within a technology (within clean or within dirty technologies) and between technologies (crossing from dirty to clean or from clean to dirty technologies).

Firms naturally recombine technologies more frequently within the same technological field. The crossing learning exists but it is less productive. This is consistent with the different laws of learning in the context of recombination exemplified by the works of Fleming (2001, 2007). When recombining knowledge inventors search and choose from knowledge that is "locally" available. In other words they experiment in fields close to their current expertise (Cyert and March 1992) and tend to ignore existing paths too far from their knowledge base (Levinthal, 1997; Nerkar, 2003). Inventors searching to innovate in clean technologies primarily begin to investigate in fields similar to what they already know in terms of technological knowledge related to "clean invention". Recently Dechezleprêtre et al. (2013) showed that intensity of knowledge spillovers (of all kinds) was stronger for clean than dirty technologies. The authors put forward two explanations for this: clean 
technologies have more applications and opportunities than dirty technologies and are thus more likely to be influenced by other technologies. They also supposed that derived inventions are more likely to be radically new compared with dirty technologies. Indeed, the literature on absorption often emphasizes that external knowledge is a key input in the production of inventions but that external sourcing matters even more for breakthrough inventions (see Zahra and George, 2002).

From the literature, we deduce that the impact of past knowledge accumulated in clean technologies (dirty technologies) should be larger than the impact of dirty technologies (clean technologies) when the present invention in clean technologies (dirty technologies) is at stake. At the industry level, Woerter et al. (2002) found that past surrounding alternative technology capacities influence clean technology inventions but in a moderate way compared with the surrounding clean-tech pool of knowledge. On individual firms belonging to the car industry Aghion et al. (2015) found similar results: spillovers matter for inventions in clean technologies and matter more when they are "within technologies".

Knowledge sourcing can be either an internal learning process, where firms ground their present inventions on their own past experience, or an external learning process, where firms draw on past inventive activities by other firms and public research organizations. Despite the lack of evidence, the importance and the excellence of national public research organizations and their ability to transfer their knowledge efficiently to firms could be critical, especially for local firms (Cainelli et al, 2012). More generally, the national institutional setting in which a corporation is embedded plays a role (see Breschi et al. 2003). However, firms and especially MNEs, can source knowledge in their country or can access knowledge abroad (Chung and Yeaple, 2008) and arbitrate among national specificities (Nandkumar and Srikanth, 2015). A core assumption in the literature is that local knowledge is easier to absorb than geographically distant (international) knowledge (Aghion et al., 2015). The volume of external knowledge a firm can access, its localization, as well as its balance between clean and dirty technologies, are thus likely to influence current decisions regarding the commitment of firms to clean technologies. At the industry level, Woerter et al. (2002) confirmed the dominance of internal learning over external learning. Their results also confirmed Jaffe and Palmer's work (1997) showing the positive and significant role of international spillovers as well as the dominance of national spillovers. At the firm level, Aghion et al. (2015) also found a dominant effect of intra-firm learning in the car industry.

Following the insights from the reviewed literature we propose a set of 4 hypotheses:

H1. When the past stock of knowledge in clean technologies increases, the amount of clean inventions in the current period also increases (positive internal within learning effect). The same relationship holds for dirty technologies.

H2. When the past stock of knowledge in non-clean technologies increases, the amount of clean inventions in the current period also increases (positive crossing learning effect).

H3. For clean innovations: the effect of the internal within-firm learning effect is larger than the cross learning effect between firms. The same relationship holds for dirty innovations.

H4. Firm knowledge absorption (inter-firm spillover effect) in the fields of clean (dirty) technology should have a positive impact on the number of clean (dirty) innovations.

\section{Methods}

This section provides information on firm patent data, variables which we built and the econometric model we implemented.

\subsection{Data}


The use of patent data as a proxy for inventive activities in environmental fields of activities is now very common (see Brunnermeir and Cohen, 2003; Nameroff et al.; 2004; Wagner; 2007). With respect to clean invention patterns, particular features have been highlighted. Johnstone et al. (2008), studying the case of renewable energy over the period 1978-2003 for OECD countries through EPO patenting, record a rapid growth in wind and waste-to-energy invention activity since the mid-1990s. In this specific energy field, the percentage of patent applications normalised by overall patenting equals approximately 3\% for many countries (Johnstone et al.'s paper does not provide the amount for the overall sample). Certain countries emerge as technological leaders (this role may be biased because of home or continent bias in EPO patenting), the percentage equalling approximately 6-7\%, as follows: Austria (solar and geo-thermal), Australia (geo-thermal and ocean), Spain (wind and solar), and Norway (wind, solar, ocean). Denmark scores well in wind energy with a $12 \%$ share of renewable energy patents. Conversely, the percentages for France and the USA are only slightly above 2\%.

In our research, we used patent information including applicant names, the date of application filing date, inventors' addresses and technology classification (using fractional counting) ${ }^{11}$. We collected patent data extracted from the Patstat database (version 2011) and relied on a new and large database of firms'patents developed at Ifris since 2008, the CIB database (Corporate Invention Board database) built to take into account the globalisation of corporate $R \& D$. This database includes the selected priority patent applications filled between 1986 and $2005^{12}$ (i.e., the very first patent application as a novelty) without any patent office restrictions from a group of almost two thousand large firms with the highest R\&D investments and sustained patenting activity defining for each firm a consolidated perimeter based on Orbis information. The list of firms studied was mainly provided by the Industrial R\&D Investment Scoreboard 2008 (see Hernandez Guevara et al., 2010 for a recent overview of the scoreboard). This list was complemented by Indian and Chinese firms that declared R\&D investments between 1999 and 2009 in the Computstat database and by names of the most important firms as assignees of WIPO, EPO and USPTO patents. We then collected all priority patents ${ }^{13}$ applied for by these leading firms between 1986 and 2005 (i.e., applied for by one of the firm's entities: parent firm, subsidiaries, or other firms included in the parent firm after merging or acquiring) ${ }^{14}$ and further restricted our firm sample to a subset of 946 companies with sustained inventive activities (defined as firms with more than 5 priority patents during 1994-1996 and during 2003-2005) ${ }^{15}$. The building step of the database are shown in figure 1.

\section{Insert Figure 1}

These firms applied for 706524 priority patents during 1994-1996 and 882895 in 2003-2005 (this corresponds to approximately half of the worldwide priority patent applications). To determine patents related to clean energy, we decided to select those belonging to the Y02E classification ${ }^{16}$ which collects inventive technologies in the field of energy that control, reduce or prevent greenhouse gas emissions of anthropogenic origin as set forth by the Kyoto Protocol. This classification was built using EPO experts that first select technologies or applications that have potential for mitigation of or

\footnotetext{
${ }^{11}$ More information on the data set is provided by Laurens et al. (2015).

${ }^{12}$ When the firm database was built on an ealier version of Patstat (2009), the latest available year with a complete collection of patent applications in the database was 2005. For more recent years, the patent collection was not yet completed.

${ }^{13}$ Priority patent count data have many advantages (see de Rassenfosse et al., 2013).

${ }^{14}$ Using the Orbis database edited by Bureau van Dijk Electronic Publishing we defined the global ultimate owner (GUO) for each of the firms and identified all subsidiaries in which one of the GUOs had more than $50.01 \%$ of shares.

${ }^{15}$ See the paper by Vezzani et al. (2014) for an overview on PATSAT matched with the EU scoreboard firms in other technological fields.

${ }^{16}$ A great deal of literature deals with the problem of the delineation of technologies in nanotech (see Foray et al., 2010 and references therein), in biotech (OECD, 2005) and of course in environmental technologies (see Oltra et al., 2010; Haščič and Migotto, 2015). The Y02E classification proposed in 2012 was a major improvement in identifying environmental innovation (Haščič and Migotto, 2015) and is now used by specialists to mitigate identification problems (Leydesdorff et al., 2015).
} 
adaptation against climate change. They then define procedures to retrieve the relevant patents relying both on existing classifications (ICP, ECLA) and lexical analysis of abstracts or claims. (EPO, 2010, Veefkind et al., 2012 for details). As these procedures remain undisclosed, users are prevented for knowing if a given technology is included or not. However, since it combines both classifications and lexical analysis made by experts of each technology, it would seem to us to be a reliable database to broadly investigate energy greentech, saving time and human resources which would be required to build our own energy greentech database. The Y02 classification is now widely adopted by researchers using greentech patents (Bointner, 2014; Frankhauser 2013, Laurens et al., 2015). Other databases have been built to delineate greentech or environmentally friendly technologies, for example the "Green Inventory" developed at WIPO and "ENV-Tech" set up by OECD. Both of these rely only on a selection of IPC codes. In order to focus on a specific type of technology or application, it is still necessary to build one's own database and Green Inventory or ENV-Tech may constitute a good starting point. Many strategies (or combined strategies) can thus be used based on selection of class, lexical analyses ${ }^{17}$, patent citations for more precise delineation (Corrocher et al., 2007; Cecere et al., 2014).

From 1986 to 2005, our set of firms applied for 99773 Y02E priority patents. During the period 1994$1996,1.62 \%$ (11 445 patents) of all our firms' patents belonged to theY02E classification. This share grew to $2.30 \%$ (20 273 patents) in 2003-2005. Despite this increasing share of clean inventions in the firm patent portfolio, the contribution of large firms to all worldwide energy clean technology patenting declined over the period. However, their contribution to technology remained higher in clean inventions than in other technologies.

The Y02E label covers a large range of clean energy technologies. In our final corporate patent dataset, $68.2 \%$ of the patents were in the field of "Technologies with contribution to GHG emissions mitigation" (this covers energy storage (batteries) (44.8\%), fuel cells (17.1\%), hydrogen technology $(2.2 \%)), 18.4 \%$ related to "Renewable energy sources" (including photovoltaic (13.3\%), wind (1.8\%), thermal solar $(1 \%)$, hydro $(2.1 \%)$, oceanic $(0.7 \%)$ and geothermal $(0.1 \%)$ energies), $3.4 \%$ were in "Nuclear Energy", $2.6 \%$ were in "Technologies for the production of fuel of non-fossil origin" (biofuel $(0.7 \%)$, from waste $(1.9 \%)$ ), $2.6 \%$ were in "Combustion technologies with mitigation potential" (Combined Heat and Power) and $2.6 \%$ were in "Technologies for efficient electrical power generation, transmission or distribution".

\section{Insert Table 1 \\ Insert Table 2}

Tables 1 and 2 show a firm's distribution, total patents and clean energy patents according to the firm's global headquarters location. In North America and Europe, the share of firms largely exceeds their share of patents, whereas the opposite is true for Asia (where one quarter of firms produce more than three quarters of the patents). This overwhelming contribution of Asian patents is largely the consequence of the institutional bias induced by counting priority patents ${ }^{18}$. However, this does not prevent an unbiased comparison of the share of clean patents of a group of firms (from a given country or industry) with the share of the same group when considering all technologies. In European countries (with the exception of France due to its specialization in nuclear energy) and in the United States, firms' commitment to clean energy patenting is significantly lower than in all other Technologies. The opposite is observed for Japanese firms (cleantech intensity, i.e., the share of clean patents/share in all patents, is $3 / 4$ in Japanese firms, $1 / 2$ in US and 2/3 in Germany). Two industries contribute to more than

\footnotetext{
${ }^{17}$ In our opinion, lexical analysis is a powerful tool to retrieve scientific publications in a given field, but is less adapted for patents where lexical terms are often less meaningful.

${ }^{18}$ It counts as equal those patents applied for in different patent offices where the rules for patenting can differ to a large extent. For example, the level of inventiveness to apply for a patent is Japan is lower than in patent offices in western countries. However counting priority patents avoids national bias, encompasses all patents without any selection. Furthermore, using the first application for the first invention, means that the filing date is closer to the invention date.
} 
$50 \%$ of clean energy patenting, "Industrial goods \& services" and "Automobiles \& parts"19, the latter being more focused on clean energy patenting (cleantech intensity: $1.8(=26.2 / 14.8$ from table 2$)$ than the former $(1.1(=28.7 / 27.3$ from table 2$))$. Not surprisingly, the "Utilities" industry is also intensively focused on clean patents (intensity of 5), but this sector contributes only $3.6 \%$ to clean energy patenting.

\subsection{Variables definition,}

\section{Explained variables}

$\mathrm{PAT}^{\mathrm{k}}{ }_{\mathrm{i}}$ is the flow of patented inventions over the 2003-2005 period. Each invention is counted once using the priority number or patent family whenever the patent is filed in several countries. There is no weight assigned to the quality of the patented innovation. Counting is fractional; firms may share properties with co-applicants. In this case, we consider a weight that is the inverse of the number of co-applicants. Nevertheless, counting cannot be considered as continuous; to preserve the counting property, the number of fractional patents is grounded. $\mathrm{k}$ is the technology embedded in the invention. In this article, $\mathrm{k}$ is a set reduced to two types of technologies in accordance with Aghion et al. (2012): clean technologies ( $\mathrm{C}$ thereafter) and dirty technologies (D thereafter). Thus, a single firm can produce inventions in both fields. In addition to the count variable PAT, we also defined LPAT as log $(\mathrm{PAT}+1)$.

\section{Explanatory variables}

The following are the two main explanatory variables:

1. Own Stock Clean Patents a proxy for a firm's learning capacity in the field of clean energy technology.

2. Own Stock Dirty Patents a proxy for a firm's overall learning capacity (all technological fields except clean technologies)

The two Firm patent stocks are computed for the period 1986-2002. We use the perpetual inventory method (Cockburn and Griliches, 1988). However, this is approximated using the cumulated inventions over the 1986-2002 period:

$$
\mathrm{K}^{\mathrm{k}}{ }_{\mathrm{it}}=\mathrm{PAT}^{\mathrm{k}}{ }_{\mathrm{it}}+(1-\delta) \mathrm{K}_{\mathrm{i}, \mathrm{t}-\mathrm{1}}^{\mathrm{k}}
$$

where $\mathrm{k}=\mathrm{C}, \mathrm{D}(\mathrm{C}=$ clean, $\mathrm{D}=$ dirty $)$. We use a knowledge depreciation rate, $\delta$, which is $15 \%$. This choice is subjective but is one often adopted in the $R \& D$ literature. Addressing top R\&D investors, who are likely to be at technology's edge, the depreciation rate is likely to be biased towards a higher level. We therefore consider $20 \%$ and $30 \%$ for robustness checks. Note that the stock of patents is computed based on the localisation of the inventors. We thus implicitly assume that knowledge circulates easily inside our large firms.

In addition to the two firm patent stocks of knowledge, we compute the stock of potential knowledge spillovers likely to be absorbed by firms. This establishes a proxy for a firm's capacity to absorb knowledge related to clean (or dirty) technologies from other firms. The computation of SPILLOVERS $_{\mathrm{i}}^{\mathrm{i}}$, with $\mathrm{k}=\mathrm{C}, \mathrm{D}$, is the stock of knowledge produced by other entities that firms can access and benefit from. These are computed in a similar manner to K, the stock of firm knowledge. Hence, the spillovers variable takes into account the externalities coming from other firms or individuals but also covers the set of inventions made by public research organisations. We consider the localisation of inventors as in Aghion et al. (2013), to differentiate the accessibility of knowledge for firms depending on the localisation of their R\&D facilities (inventors' location). We consider that firms are more likely to access external knowledge if their inventors are close to knowledge producers. Two geographic zones are taken into account. First is the domestic zone where firms that are considered from a country $\mathrm{m}$ are likely to access the national stock of knowledge. Thus, using the

\footnotetext{
${ }^{19}$ The strong commitment of car manufacturers to clean patenting is linked to the boom of patents in batteries and fuel cells since the late 1990s. They represent more than half of the clean patents of our dataset.
} 
personal address of inventors, we compute $\mathrm{s}_{\mathrm{i}}^{\mathrm{h}}$ as the share of firm i's inventions invented in its home country h between 1986 and 2002 . We thus can define $s_{i}^{f}=\left(1-s_{i}^{h}\right)$ as the share of firm i's inventions invented abroad between 1986 and 2002. For example, a US firm with a stock of 1000 inventions over the 1986-2002 period with 150 inventions created in the USA has $s_{i}^{h}=0,15$ and $s_{i}^{f}=0,85$. In accordance with the previous definition of knowledge stock, we can compute the knowledge stock between 1986 and 2002 accumulated by worldwide organisations other than firm i. We distinguish the national stock of knowledge $\sum_{i \neq j} K_{j h}^{k}$, which is the pool of clean or dirty knowledge produced in the home country h of firm i likely to be received by firm i, and the national stock of knowledge $\sum_{i \neq j} K_{j f}^{k}$, which is the pool of foreign clean or dirty knowledge produced in all the foreign countries, $\mathrm{f}$, that are also likely to be received by firm i:

We thus define the spillovers likely to benefit to firm i as:

$$
\text { SPILLOVERS }_{i}^{k}=s_{i}^{h} \sum_{i \neq j} K_{j h}^{k}+s_{i}^{f} \sum_{i \neq j} K_{j f}^{k}
$$

where $\mathrm{k}=\mathrm{C}, \mathrm{D}$. We thus assume that a firm with only national $\mathrm{R} \& \mathrm{D}$ facilities will not be able to access the world's pool of knowledge. However, firms exclusively conducting their R\&D abroad will not be able to assess and benefit from the knowledge produced in their home country by competitors or other organisations. Still, they are likely to absorb knowledge produced abroad either by other firms or by foreign public research labs, and thus benefit indirectly from other countries' environmental policies. We did not further compute dirty and clean $\mathrm{s}_{\mathrm{i}}$ indexes based on technologies: the share of clean in its home country and the share of clean inventions filed abroad. Doing so, we considered that the experience with invention is generic: experience with dirty tech allows firms to benefit from clean tech knowledge pools and experience with clean tech also allows firms to benefit from the knowledge pool on dirty tech. In this setting, a firm experienced in dirty technologies and entering clean tech thus will potentially benefit from previous inventions made in clean tech by other firms at the national and international level ${ }^{20}$.

An important point is that, in order to facilitate the interpretation of coefficients, the different explanatory variables defined above are taken in logarithm ${ }^{21}$.

At the firm level, we defined additional variables to control for sectoral fixed effects. Using the OECD classification of industries and services, we defined six different dummies based on the industry R\&D intensity: Low Tech, Medium Low Tech, Medium High Tech, High Tech, Knowledge intensive services (KIS) and Low Knowledge Intensive service (LKBIS=1) sectors (Eurostat). We further defined a set of industries in which energy is core and thus innovation around clean technologies is critical. The definitions of these variables are detailed in appendix 1.

In order to take into account the differences among countries, we further controlled for the national heterogeneity introducing national dummies or national variables. Differences in national market size and wealth are likely to influence the ability of firms to develop new technologies particularly in the fields of clean technologies. The first dimension is proxied by GDP and the second by GDP per capita. In accordance with the large number of countries we have in our dataset, we cannot approximate the role of the various national policies in clean energies on the different affiliates over the period. Nevertheless, some countries may belong to economic areas with their own technology policy. Despite the difficulty to observe the different context and policies, we proposed a set of additional variables in

${ }^{20}$ Considering that dirty and cleantech are distant technologies and that two distinct absorptive capacities are then deployed by firms, alternative solutions would be to compute SPILLOVERS $S_{i}^{k}=s_{i}^{k} \sum_{i \neq j} K_{j h}^{k}+s_{i}^{k} \sum_{i \neq j} K_{j f}^{k}$ or SPILLOVERS $S_{i}^{k}=s_{i}^{k h} \sum_{i \neq j} K_{j h}^{k}+s_{i}^{k f} \sum_{i \neq j} K_{j f}^{k}$.

${ }^{21}$ When the $\mathrm{K}$ variable is null, the value of $\mathrm{K}$ is set to $\log (0.001)$. Certain $\mathrm{R} \& \mathrm{D}$ investors did not file any invention over the 2003-2005 period. In this case, the explained variables are adjusted and set to $\log (0.001)$ with dummy variables set to 1 when this adjustment occurs. 
order to control for the role home country effects. A set of country fixed effect is first introduced. In order to grasp the important differences exist in policies, including regulatory stringencies. In order to control for this possible policy, we defined a EU and USA dummy that is set to 1 for countries belonging to the EU or the USA, respectively, and set to 0 otherwise. A set of national variables are also proposed to control for the role of home effects: using the World Bank database we can introduced per capita $\mathrm{CO}^{2}$ emissions, total $\mathrm{CO}^{2}$ emissions from fossil-fuels and cement production, the percentage of forest area or the percentage of protected area in order to approximating cleantech opportunities and the possible importance of related cleantech policies.

\subsection{Econometric strategy}

To cope with the PAT variable, we implemented a negative binomial count model. We defined two cross-sectional models. Our main model explaining clean patents and the second model explaining dirty patents. The exponential models are respectively:

PAT $_{i}^{C}=\exp \left(\alpha_{1} K_{i}^{C}+\alpha_{2} K_{i}^{D}+\alpha_{3}\right.$ SPILLOVERS $_{i}^{C}+\alpha_{4}$ SPILLOVERS $_{i}^{D}+\sum \gamma$ Controls $)+\varepsilon_{i}$

and

$P A T_{i}^{D}=\exp \left(\beta_{1} K_{i}^{C}+\beta_{2} K_{i}^{D}+\beta_{3}\right.$ SPILLOVERS $S_{i}^{C}+\beta_{4}$ SPILLOVERS $_{i}^{D}+\sum$ OControls $)+\mu_{i}$

A negative binomial is sustained compared with Poisson because we rejected the hypothesis that the dispersion parameter alpha is null 0 for the different regressions with a Likelihood-ratio test ${ }^{22}$. This suggests that the explained variables are over-dispersed. The model was estimated by the maximum likelihood that is a basic estimation method in count models. Le log-likelihood function is concave and the maximum is obtained using a Newton-Raphson algorithm. The estimator is consistent and efficient. However, some difficulties may arise when is introduced some feedback effects and may not respect the strict exogeneity assumption (See Aghion et al., 2013 for a discussion). The problem, that is usually emphasized for panel data, is not tackled in our cross-section model.

In addition, we proposed an OLS estimator using the logarithm of PAT, such as LPAT=log (PAT +1$)$. In both cases, the coefficients of interest can be directly interpreted as elasticities and thus directly compared: in the count model specification, $\mathrm{K}^{\mathrm{c}}$ is the number of clean data over the 1986-2002 period but $\mathrm{K}^{\mathrm{c}}$ is in logarithm. Consequently, the $\log$ of PAT is equal to $\beta$ multiplied by the $\log$ of patent stock. $\beta$ can thus be directly interpreted as an elasticity. The coefficient for the count model is thus also directly comparable to the coefficient identified with OLS that is specified as a log-log model ${ }^{23}$.

The predictions are as follows:

a) Path dependence should imply a positive impact of a firm's stock of knowledge. This effect is expected in both types of technology according to H1. As a consequence, $\alpha_{1}>0$, and $\beta_{2}>0$.

b) $\mathrm{H} 2$ tell us that $\alpha_{2}>0$ (but we do not hypothesize that $\beta_{1}>0$ ).

\footnotetext{
${ }^{22}$ Testing $\alpha=0$ with $\operatorname{Var}(y \mid x)=E(y \mid x)+\alpha^{2} E(y \mid x)$

${ }^{23}$ The only difficulty for the reader will thus be thus the interpretation of the coefficients of the dummy control variables, when $\gamma$ departs from 0 . In this case, the magnitude of the coefficient is computed comparing the patent number predicted when the dummy set to 1 and set to $0\left(r=\frac{P A T^{1}-P A T^{0}}{P A T^{0}}=e^{Y}-1\right)$ and cannot be interpreted directly anymore since $\gamma=\ln (1+r)$ departs from $r$.
} 
c) H3 assumes an intra-technology dominant effect: $\alpha_{1}>\alpha_{2}$, and $\beta_{1}<\beta_{2}$

d) For clean (dirty) technology, we expect (see H4) a higher impact for intra-technology spillovers: $\alpha_{3}>0$ and $\beta_{4}>0$.

We cannot exclude the existence of negative spillovers, indicating a substitution between the two technologies. When less dirty knowledge is available outside of the firm, the firm is more likely to invest in clean technologies, whereas when less clean technologies knowledge are available, the firm continues to invest in dirty technologies (hence, $\alpha_{4}<0$ and $\beta_{3}<0$ ). However, we chose not to develop any related additional hypothesis here. The robustness of the parameters is tested with alternative depreciation rates, specifications and samples. A particular attention is paid to control home country effects clustering residuals on country names.

\section{Results}

Among the 946 top R\&D investors, 100\% filed at least one invention patent over the 2003-2005 period. Forty-five percent of these firms also filed at least one patent in clean technologies over the same period. Although, on average, more than 21 clean inventions were filed per company, the mean surges to 47 for the 431 firms active in clean patenting. The descriptive statistics are reported in appendix 1 showing that, on average, patent portfolios contain approximately 930 patents. More specifically, 38 firms (4\%) were active in cleantech during both periods (2003-2005 and 1986-2002). Hence, $10 \%$ of the firms that were active in cleantech during the 1986-2002 period succeeded in remaining active in this domain during the subsequent three years. In addition, $69 \%$ of firms with dirty inventions during the 1986-2002 period became active in cleantech during the subsequent three years. This result means that cleantech rapidly became a vibrant patenting field in which $91 \%$ of firms were newcomers during the 2003-2005 period. The firms involved in dirty technologies patents were more likely to belong to high tech industries or KIB services than firms patenting in cleantech areas. Firms active in cleantech were more likely to belong to low-medium tech or medium-high tech industries. Of course, many of these firms belong to energy sectors. Firms from wealthy countries or large countries were not more likely to be active in cleantech. However, firms from EU countries were less likely to be cleantech-oriented than firms from other countries.

Econometric results are reported in Table 3.

There is a robust positive association between the (past) capital of knowledge accumulated related to clean technologies and the number of clean inventions, after controlling for the effects of industry, nation and other factors (H1 cannot be rejected). A firm with a 1986-2002 stock of patents in cleantech with a $10 \%$ growth in patents is likely to increase its $2003-2005$ stock by $7.5 \%$. This result supports our first hypothesis $\mathrm{H} 1$ and the idea that learning effects fully operate in the field of clean technologies. According to $\mathrm{H} 1$, a within learning effect can also come from the production of dirty technology inventions. Table 3 shows that increasing the firm's stock of knowledge in dirty technologies by $10 \%$ increased the amount of dirty inventions by $9 \%$ over the 2003-2005 period.

Firms having a strong, consistent history in dirty technologies can also innovate in clean technologies. Increasing the firm's stock of knowledge in dirty technologies by $10 \%$ increased the amount of clean inventions by $24.6 \%$ over the 2003-2005 period. This result supports H2. However, firms with experience in dirty technologies are much more able to develop new dirty inventions from their past activities in dirty technologies than to develop new inventions in clean technologies (comparing 0.91 with 0.25 in col. 2 and col. 1 in Table 3).

Firms accumulating large technological experience in other technologies are thus better placed to obtain higher productivity in the production of clean inventions. This cross-technology learning effect internal to the firm is however small: the impact of internal (to the firm) cross-learning on the number of clean inventions produced is approximately 3 times lower than the impact of the experience in clean-tech ( 0.25 to be compared to 0.75 in col. 1, Table 3$)$. The gap between the two elasticities is 
significant (Wald critical value is $63.4, \mathrm{p}<0.01$ ) and, thus $\mathrm{H} 3$ cannot be rejected. Past investment in clean knowledge activity "pays" more than investment in other types of knowledge activity for current clean inventions.

Furthermore, Table 3 reveals that past experiences in cleantech are useless for present dirty inventions (elasticity is 0.012 , not different from 0). Hence, although intra-technology learning is found to be strong over time, intra-firm crossing-technological learning switches from dirty technology fields to clean technology fields: However, there is no evidence that the opposite is true.

Our results regarding $\mathrm{H} 1$ to $\mathrm{H} 3$ are robust and in accordance with previous results obtained at the individual level in one industry (Aghion et al., 2015). At the industry level (Stucki and Woerter, 2012) our results are robust regarding the positive intra-tech learning and the asymmetric learning effect between clean and dirty technologies. Table 4 provides a comparison between our estimated coefficients and those emanating from the two papers cited immediately above. The main difference relies on the magnitude of learning effects, which are larger than in our data. Our results are very similar to Stucki and Woerter's elasticities obtained at the sectoral level, including the similarity in the gap between intra-technology and crossing technology learning. However, the magnitudes of intrasectoral learning are found to be approximately twice as high as those for firms in the car industry (Aghion et al., 2015). Our interpretation is that learning is much higher for top R\&D investors (which constituted the firms of our sample) than for firms in car industry which encounter more difficulties in capitalising on their own knowledge.

\section{Insert Table 3}

This finding highlights that large firms' technological accumulation (our sample solely encompasses large, worldwide firms) may be a useful lever for increasing clean invention productivity. Investing in technology in the past, irrespective of the type, could be beneficial for producing clean inventions. In other words, the firm's entire technological experience (dirty technologies included) is not lost in clean energy technologies. Of course, if technological experience is achieved through investment in clean technologies then that is better. Consequently, path dependence at the firm level is characterised by a twofold process affecting clean technologies improvements. The effect of internal learning on current inventive activity is also found to be lower for clean technologies than for dirty technologies (also confirmed by Aghion et al., 2015). This may be because the class of clean technologies is younger than the class of dirty technologies. Consequently, knowledge is more difficult to codify. In addition, it is more difficult to identify the opportunities associated with new knowledge. The identification and exploitation of opportunities are much easier for dirty technology inventions where opportunities are reduced but where there is a longer past experience which is easier to exploit.

\section{Insert Table 4}

The world's leading inventors are also found to be influenced by other knowledge producers. Firms more exposed to larger stocks of clean inventions created by others are significantly more productive in clean inventions. This indicates that, in addition to an internal learning effect on clean technologies, a learning of external knowledge produced at the national or international level in cleantech fields occurs. The elasticity on clean spillovers is 0.5 . The hierarchy of coefficients is in accordance with previous results (Stucki and Woerter, 2012; Aghion et al., 2015). The spillover effect is found to be smaller than the internal learning effect in clean technologies fields. However, a Wald test suggests that the equality between the two elasticities cannot be rejected (the Wald critical value is 0.74 , $\mathrm{p}>0.38$ ). The magnitude of spillovers is also found to be larger than the internal learning occurring across technologies. The difference is no longer significant (the Wald critical value is 1.58 and p $>21 \%$ ). The negative effect of dirty spillovers is also in accordance with previous results (Stucki and Woerter, 2012; Aghion et al., 2015) and reminds us that a dynamic dirty technologies environment surrounding environment hampers the development of cleantech activities. However, our different models failed to identify any positive effect of dirty spillovers on dirty technology inventions. A dirty environment does not impact the production of dirty knowledge. As a consequence $\mathrm{H} 4$ cannot be 
rejected for clean innovations. The results show that spillover effects are found to be weaker than internal learning effects. In dirty technology fields, learning appears to be purely internal. Once more, our results are in accordance with previous results ${ }^{24}$ (Stucki and Woerter, 2012; Aghion et al., 2015).

Our results for control variables are consistent with expectations. They first show the role of technological opportunities approximated by industry fixed effects. The firms in medium-high tech industries are more productive (by $\mathrm{e}^{0.34}-1=40 \%$ ) with respect to clean technologies inventions, than firms in other industries. Firms in high-tech industries are found to be more productive in dirty (i.e., not clean) technological changes $(+27 \%)$. These finding are not surprising. In the first category, we find firms from sectors making large efforts to economise and "clean" energy such as manufacturers of chemicals, electrical equipment, and motor vehicle. In contrast, it is widely acknowledged that firms in high-tech sectors mainly concentrate their R\&D efforts on very new technologies and do not consider clean inventions as a priority. Knowledge intensive business services (KIBS) are also found to consist primarily of firms patenting more than low-tech firms in cleantech $(+39 \%)$. We also added a dummy for firms operating in the energy sector. These firms are significantly more productive in clean technology changes but also are productive in "dirty" technological inventions (respectively, $+36 \%$ and $+35 \%$ of the number of patents). In other words, there are many innovations in many directions. The country variables tell us that the economic size of the country plays a similar negative role in firm inventive productivity (regardless of the type of technology). However, this effect is significant only for $10 \%$ for clean inventions. Thus, national market size does not appear to be a lever for firms to produce new inventions. Large firms from small countries are likely to be more active than others. The technological level of the country (as measured by the variable GDP per capita) also has a significant and negative impact on a firm's clean invention productivity or dirty invention productivity. However, the magnitude of the negative impact of the technological level (the same as for dirty technological change) is two times high for clean patents than for dirty patents (elasticity is -0.33 and -0.16 , respectively). In other words, country size and wealth do not appear to be significantly related to the ability of large firms to produce knowledge in clean fields. An EU dummy was not found to be influential on clean technologies, although it did significantly lower the number of dirty inventions. This result suggests that EU policies and regulations do not help firms to develop new clean technologies. However, these policies and regulations genuinely hamper the development of dirty technologies $(-14.7 \%)$. The introduction of a USA dummy brings collinearity problems with the GDP and spillovers variables. The results (not reported) show however that firms based in the USA are patenting about $60 \%$ less in clean technologies than the firms settled elsewhere. It further underlines a significant gap between the USA and EU about the same magnitude suggesting that the regulation and energy policies are less stringent in the USA.

Our results are robust to many different specifications (available upon request). Different obsolescence rates, clustering residuals on country names, and using a log-log model, (refer to the note in Table 5 for further details) did not modify the results regarding our hypotheses. Further robustness checks were performed. Additional variables were first introduced. For example, at the firm level, we controlled for the firm labour productivity. At the national level, we also controlled for technological diversification or market concentration without challenging our results. At the country level, we tried to further control for national heterogeneity by introducing national variables from the World Bank database (per capita $\mathrm{CO} 2$ emissions, total $\mathrm{CO} 2$ emissions from fossil-fuels and cement production, the percentage of forest area or the percentage of protected area) approximating cleantech opportunities and the importance of cleantech policy. None of these national variables was found significantly related to invention levels in our different specifications. To check for possible sample biases, we finally tested our two main models on different subsets of countries. Removing Asian countries (excessively voluminous domestic patenting), small countries (headquarters in Singapore, Hong Kong, Lichtenstein, and Panama), and the energy sector did not change our results regarding our hypotheses.

\footnotetext{
${ }^{24}$ Two variables not included in the final estimation have no impact: the firm level of R\&D internationalisation and the degree of firm technological diversification.
} 
When solely USA firms were considered or when they are completely removed from our sample, H1 to $\mathrm{H} 3$ continued to hold, but spillover effects were no longer significant.

\section{Insert Table 5}

\section{Conclusion}

This paper uses a large patenting data set related to inventions produced by 946 large firms (i.e. global firms funding R\&D activity at large scale). Thanks to a new EPO classification, we were able to assess the level and the evolution of their clean (energy) inventions. We showed that overall, they produce increasingly fewer clean inventions (down from $75 \%$ to $50 \%$ of the worldwide flow in the last time period under observation).

Our main results concern the positive effects of knowledge capital (in clean and not-clean technologies) on a firm's innovative performance in clean innovations. We find that the generation of technological knowledge is an historic process characterised by clear elements of path-dependent persistence. The specific endowment accumulated in the past and represented by the firm's stock of technological knowledge, has effects on the current capability of firms to generate new technological knowledge. We provide empirical evidence for the fact that path-dependence also relies on a crossing-technological learning process: firms involved historically in dirty patenting are more likely today to produce clean inventions. Furthermore, our study puts forward the key role played by technological spillovers making the production of new technological knowledge possible. In addition to this internal (to the firm) learning effect, external-related knowledge learning in clean technologies area occurs, supporting the idea that firm knowledge absorption has a positive impact on the amount of clean innovation. However, due to the multinational nature of our large firms, we cannot disentangle their national and international origins. The results on spillovers are also in accordance with the literature, suggesting that strategic spillovers may be not dominant in industry compared with technological spillovers. In other words, our results could suggest that top players may not file patents primarily for dissuasion purposes. They also confirm the recent insights on the production of firm new knowledge and particularly provide support to theoretical advances regarding the complex process of path dependence and firm innovation persistence (see Le Bas and Scellatto, 2014; Antonelli and Colombelli, 2013).

In contrast to previous studies, our results appear more general (unlike the Aghion et al. 2015 study which focused on a single industry) and more relevant because they are directly connected to the decisions taken by firms which constitute the basic unit of analysis (unlike the paper by Stucki and Woerter 2012 who carried out their analysis at the industry level). Finally, our findings bring a likely explanation for the evidence that the clean innovation machine has not yet been fully activated (Aghion et al., 2009; Stucki and Woerter 2013). Learning takes time and so one must wait before highly productive research in clean technologies can be triggered. To our knowledge, this point has not been emphasised thus far.

With respect to policy implications our study provides interesting implications. The fact the firms with a dense history of clean inventions are more productive in that field should encourage public authorities to provide incentives to the firms to target, very early on, their R\&D investments in that direction. Conversely, because of the fact the firms having a consistent capital of knowledge in dirty technologies can innovate in clean technologies as well, they have opportunities for creating a capital of knowledge in clean energy technologies. Consequently, a high level of commitment in technological activities may be a lever for "cleaning technological development". Direct and indirect support must be provided to firms to help them to derive clean technology from their experience in dirty technologies, specifically, support for the training and hiring of complementary human resources needed to elaborate new clean knowledge from old dirty knowledge (for support see Antonioli et al., 2013). Our results on past dependence suggest that barriers may limit access to clean technology production for new firms legitimating the particular actions implemented for start-ups operating in clean fields. Still, these policy implications are country based. Our results also suggest that the country context may be not critical for top R\&D players. Firms sourcing knowledge abroad 
are likely to benefit from different national clean technologies policies. They have to arbitrate between different institutional systems.

Future extensions have previously been expected. To mitigate the well-known problem that many patents have no value or that home effects can bias our results, we expect to use triadic patent families to check the results robustness. What would be more interesting would be to account for why incentives may be different in energy sectors. Additional controls for sectoral policies and specialization could be introduced in order to explain such results. A second interesting follow-up study of the work we introduce here could be to check whether our results on path dependence apply to different types of clean energy technologies (as pictured in Popp et al., 2011 for example) such as renewable energy sources. Finally, despite efforts to consider cleantech policies, the role of public research organizations is still overlooked in our types of model which pool academic and nonacademic knowledge. One major contribution to the literature on knowledge accumulation in cleantech fields would be to disentangle academic patenting (e.g. Lissoni et al., 2013) in order to identify its influence on top cleantech players. 


\section{References}

Acemoglu, D. (2002). Directed Technical Change. Review of Economic Studies, 69(4):781-810.

Acemoglu, Daron, Philippe Aghion, Leonardo Bursztyn, and David Hemous, (2012), "The Environment and Directed Technical Change." American Economic Review, 102(1): 131-66.

Aghion, P., Dechezlepretre, A., Hemous, D., Martin, R., and Van Reenen J. (2015). Carbon Taxes, Path Dependency and Directed Technical Change: Evidence from the Auto Industry, forthcoming in the Journal of Political Economy.

Aghion P., Veugelers R., and Serre C., (2009) "Cold Start for the Green Innovation Machine". Bruegel Policy Contribution, 2009/12.

Ambec, S., Cohen, M., Elgie, S. and Lanoie, P. (2013) The Porter Hypothesis at 20: Can Environmental Regulation Enhance Innovation and Competitiveness? Review of Environmental Economics and Policy7 (1), 2-22.

Antonelli C. and A. Colombelli (2013) "Knowledge cumulability and complementarity in the knowledge generation function," Department of Economics and Statistics Cognetti de Martiis. Working Papers 201305, University of Turin.

Antonelli C., (2008), Localised Technological Change. Towards the Economics of complexity, Routledge, Oxord

Antonelli C., (ed.) (2011), Handbook on the economic complexity of technological change. Edward Elgar, Cheltenham.

Antonioli, D., Mancinelli, S., Mazzanti, M., (2013) "Is environmental innovation embedded within high-performance organisational changes? The role of human resource management and complementarity in green business strategies," Research Policy, Elsevier, vol. 42(4), pages 975-988

Archibugi D. and B. Lundvall, 2001 The Globalizing Learning Economy: D. Archibugi, B. Lundvall (Eds.), Oxford University Press, Oxford, pp. 307

Bansal P. and K. Roth (2000) "Companies Go Green: A Model of Ecological Responsiveness", Academy of Management Journal, Vol. 43, n.4, pp. 717-736.

Baumol W., (2002), The Free-Market Innovation Machine:Analyzing the Growth Miracle of Capitalism. Princeton University Press.

Bointner R., (2014), Innovation in the energy sector: Lessons learnt from R\&D expenditures and patents in selected IEA countries, Energy Policy, Volume 73, October 2014, Pages 733747.Borghesi, S., Cainelli, G., \& Mazzanti, M. (2015). Linking emission trading to environmental innovation: evidence from the Italian manufacturing industry.Research Policy, 44(3), 669-683.

Borghesi, S., Cainelli, G., Mazzanti, M., (2012). Brown Sunsets and Green Dawns in the Industrial Sector: Eco Innovations, Firm Behavior and the European Emission Trading. Working Paper 3. Fondazione Eni Enrico Mattei.

Brouhle, K., Graham, B., Harrington, D.R., (2013). Innovation under the Climate Wise program. Resour. Energy Econ. 35 (2), 91-112.

Brouillat, E., Oltra, V., Saint-Jean, M., (2013), Les trajectoires de l'éco-innovation dans l'industrie. Un premier bilan des recherches, Economie Appliquée, tome LXVI (4), pp. 83-115

Brunnermeier S. B. and Cohen M. A. (2003), "Determinants of environmental innovation in US manufacturing industries," Journal of Environmental Economics and Management, Elsevier, vol. 45(2), pages 278-293, March.

Cainelli, G., Mazzanti, M., \& Montresor, S. (2012). Environmental innovations, local networks and internationalization. Industry and Innovation, 19(8), 697-734.

Carrión-Flores, C.E., Innes, R., Sam, A.G., (2013). Do voluntary pollution reduction programs (VPRs) spur or deter environmental innovation? Evidence from 33/50. J. Environ. Econ. Manag. 66 (3), 444-459.

Cecere G., Corrocher N., Gossart, C. Ozman, M., (2014), Technological pervasiveness and variety of innovators in Green ICT: A patent-based analysis Research Policy 43 (2014) 1827-1839)

Chassagnon V., Haned N., (2013), PME et innovation environnementale : une étude empirique sur données d'entreprises françaises. Economie Appliquée, $n^{\circ} 4$. Dec. 
Chung, W., \& Yeaple, S. (2008). International knowledge sourcing: Evidence from US firms expanding abroad. Strategic Management Journal, 29(11), 1207-1224.

Cockburn, I. and Griliches Z., (1988). "Industry Effects and Appropriability Measures in the Stock Market's Valuation of R\&D and Patents," American Economic Review, American Economic Association, vol. 78(2), pages 419-23, May.

Cohen, W. M., \& Levinthal, D. A. (1990). Absorptive capacity: A new perspective of learning and innovation. Administrative Science Quarterly, 35(1990), 128-152.

Corradini, M., Costantini V., Mancinelli, M., Mazzanti, M., (2014), Unveiling the dynamic relation between R\&D and emission abatement. National and sectoral innovation perspectives from the EU, Ecological Economics, Vol. 102, pp. 48-59.

Corradini, M., Costantini V., Mancinelli, M., Mazzanti, M., (2015), Interacting innovation investments and environmental performances: a dynamic impure public good model, Environmental Economics and Policy Studies, Vol. 17, pp. 109-129.

Corrocher, N., Malerba, F., and Montobbio, F. , (2007), Schumpeterian patterns of innovative activity in the ICT field, Research Policy 36 (2007) 418-432),

Crabb, J. M. and Johnson, D. K. N. (2010). Fueling Innovation: The Impact of Oil

Cuerva M.C., Triguero-Cano A., Córcoles D., (2013), Drivers of green and non-green innovation: empirical evidence in Low-Tech SMEs. Journal of Cleaner Production.

Cyert,R ., J. G. March, (1992), A Behavioral Theory of the Firm. Prentice Hall, Englewood Cliffs. NJ.

De Marchi V., R Grandinetti (2012) Who are the green innovators? An empirical analysis of firm's level factors driving environmental innovation adoption. paper presented at the 2012 DRUID conference.

De Marchi V., R Grandinetti (2013), "Knowledge strategies for environmental innovations: the case of Italian manufacturing firms", Journal of Knowledge Management. Vol. 17, $\mathrm{n}^{\circ}$ 4, pp 569-582.

De Marchi V., Grandinetti R., Cordeiro J., (2015), Firms-level and industry-level factors as drivers of environmental innovations. Presentation FEEM-IEFE Joint Seminar Series. $26^{\text {th }}$ March.

Dosi, G. (1997). Opportunities, incentives and the collective patterns of technological change, Economic Journal, vol. 107, 1530-1547

Eberlain B., Matten D., (2009), "Business Responses to Climate Change Regulation in Canada and Germany: Lessons for MNCs from Emerging Economies". Journal of Business Ethics (2009) $86: 241-255$.

EPO (2010) : «Patents and clean energy: bridging the gap between evidence and policy », UNEPEPO-ICTSD..

http://documents.epo.org/projects/babylon/eponet.nsf/0/cc5da4b168363477c12577ad00547289/\$FI LE/patents_clean_energy_study_en.pdf

Fleming L. et Szigety M., (2006), «Exploring the tail of creativity : an evolutionary model of breakthrough invention », in : J. A. C. Baum, D. D. Stanislav, A.Van Witteloostuijn, (eds.), Advances in Strategic Management, Part V: Technology Strategy, vol. 23, pp. 335-359Frankhauser S., (2013), 'Who will win the green race? In search of environmental competitiveness and innovation, Global Environmental Change, 23(5) 902-913

Foray, D., Lhuillery, S., \& Raffo, J. (2010). Le positionnement et les perspectives stratégiques des nanotechnologies en France (No. EPFL-REPORT-161963).

Galliano D. and Nadel S., (2013), Les déterminants de l'adoption de l'éco-innovation selon le profil stratégique de la firme : le cas des firmes industrielles françaises. Revue d'économie industrielle. pp. 77-110.

Ghisetti C., Quatraro F., (2014), Is green knowledge improving environmental productivity? Sectoral evidence from Italian regions. Workings Papers series 11/14. Department of Economics and Statistics "Cognetti de Martiis".

Ghisetti, C., \& Pontoni, F. (2015). Investigating policy and R\&D effects on environmental innovation: A meta-analysis. Ecological Economics, 118, 57-66.

Gilli M., Mancelli S., Mazzanti M., (2013) Innovation Complementarity and Environmental Productivity Effects: Reality or Delusion? Evidence from the EU. FEEM Working Paper No. 88.2013 
Griliches Z., (1995), 'R\&D and productivity', in: P. Stoneman (ed.), Handbook of the Economics of Innovation and Technological Change, Massachusetts: Cambridge Press, 52-89.

Hagedoorn, J. \& Wang, N., (2012), Is there complementarity or substitutability between internal and external R\&D strategies? Research Policy. 41, 6, p. 1072-1083.

Haščič, I., \& Migotto, M. (2015). Measuring environmental innovation using patent data. OECD Working paper, OECD, Paris.

Hassler J., Per Krusell, Conny Olovsson, (2012), Energy-Saving Technical Change. NBER Working Paper No. 18456

Hernandez Guevara, H., Tuebke, A., Hervas Soriano, F., \& Cincera, M. (2010).The 2010 EU Industrial R\&D Investment Scoreboard (No. JRC61230). Institute for Prospective and Technological Studies, Joint Research Centre.

Hicks, J. R. (1932). The Theory of Wages.

Horbach J., Rammer C. and Rennings K., (2011), "Determinants of Eco-innovations by Type of Environmental Impact: The Role of Regulatory Push/Pull, Technology Push and Market Pull", ZEW Discussion PaperN ${ }^{\circ} 11-027$.

Horbach, J., (2008), «Determinants of environmental innovation - New evidence from German Panel data sources », Research Policy, vol. 37, n 1, p. 163-173.

Hughes K., (1986), Exports and Technology, Cambridge University Press, New York.

Jaffe A. B. et al., (1995). "Environmental Regulation and the Competitiveness of U.S. Manufacturing: What Does the Evidence Tell Us?," Journal of Economic Literature, American Economic Association, vol. 33(1), pages 132-163, March.

Jaffe A.B., R. Newell, R. Stavins, (2002), Environmental policy and technological change, Environ. Resource Econ. 22. 41-69.

Jaffe A.B., Richard G. Newell \& Robert N. Stavins, (2000). "Technological Change and the Environment," NBER Working Papers 7970, National Bureau of Economic Research, Inc

Jakobsen S. and Clausen T. H., (2013), Comparing the innovation process in green and non-green firms: A look at barriers to innovation? Druid Academy 2013.

Johnstone N., Haščič I., Popp D. (2008) "Renewable Energy Policies And Technological Innovation: Evidence Based On Patent Counts". NBER Working Paper No. 13760. Issued in January 2008. 34 pages.

Johnstone, N., Haščič, I., \& Popp, D. (2010). Renewable energy policies and technological innovation: evidence based on patent counts. Environmental and Resource Economics, 45, 133155.

Johnstone, N., Haščič, I., Poirier, J., Hemar. M., Michel, C. (2012) Environmental policy stringency and technological innovation: evidence from survey data and patent counts. Applied Economics 44 (17), 2157-2170.

Kemp R. and Foxon T., (2007), 'Typology of eco-innovation', European Project 'Measuring ecoinnovation' (Call FP6-2005-SSP-5A, Area B, 1.6, Task 1).

Kesidou E. and Demirel P. (2012) "On the drivers of eco-innovations: Empirical evidence from the UK," Research Policy, Elsevier, vol. 41(5), pages 862-870.

Kesidou, E., Demirel, P., 2012. On the drivers of eco-innovations: empirical evidence from the UK. Research Policy 41 (5), 862-870.

Khanna, M., (2001), «Non-mandatory Approaches to Environmental Protection», Journal of Economic Surveys, vol. 15, n ${ }^{\circ}$ 3, p. 291-324.

Klepper, S. (1996). Entry, exit, growth, and innovation over the product life cycle. American Economic Review, 86(3), 562-83.

Klitkou, A., Bolwig, S., Hansen, T., \& Wessberg, N. (2015). The role of lock-in mechanisms in transition processes: The case of energy for road transport. Environmental Innovation and Societal Transitions.

Lanjouw J.O. and Mody A., (1996) Innovation and the international diffusion of environmentally responsive technology. Research Policy 25, 549-571.

Lanjouw, J., Mody, A., (1996). Innovation and the international diffusion of environmentally responsive technology. Research Policy 25, 549-571. 
Laurens P., Le Bas C., Schoen A., Villard L., Laredo P. (2015) The rate and motives of the internationalisation of large firm R\&D (1994-2005): Toward a turning point? Research Policy 44: 765-776.

Laurens P., Le Bas C., Schoen A., Lhuillery S. (2015) Technological contribution of MNEs to the growth of energy-greentech sector in the early post-Kyoto period. Environ. Econ. Policy Studies, DOI 10.1007/s10018-015-0125-2.

Le Bas C. and Scellatto G., (2014), Firm innovation persistence: a fresh look on the frameworks of analysis. Economics of Innovation and New Technologies. Volume 23, Issue 5-6, pages 423-446.

Levinthal, D. A. (1997). Adaptation on rugged landscapes. Management Science. 43 934-950.

Lepoutre J., Heene A., (2006), Investigating the Impact of Firm Size on Small Business Social Responsibility: A Critical Review, Journal of Business Ethics, Springer, vol. 67(3), pages 257-273, September.

Leydesdorff, L., Alkemade, F., Heimeriks, G., \& Hoekstra, R. (2015). Patents as instruments for exploring innovation dynamics: geographic and technological perspectives on "photovoltaic cells". Scientometrics, 102(1), 629-651.

Lissoni, F., Llerena, P., \& Sanditov, B. (2013). Small worlds in networks of inventors and the role of academics: An analysis of France. Industry and Innovation, 20(3), 195-220.

Lynch-Wood G, Williamson D, Jenkins W. 2009 The over-reliance on self regulation in CSR policy. Business Ethics: A European Review18 (1): 52 - 65.

Malerba, F and L Orsenigo (1999). Technology entry, exit and survival: An empirical analysis of patent data. Research Policy, 28(6), 643-660.

Marin, Giovanni \& Mazzanti, Massimiliano, 2009. "Emissions Trends, Labour Productivity Dynamics and Time-Related Events - Sector Heterogeneous Analyses of Decoupling/Recoupling on a 1990-2006 NAMEA," MPRA Paper 17903, University Library of Munich, Germany.

Models and Empirical Tests. Center for Sustainability Management.

Montero J.P., (2002), Permits, standards and technology innovation, J. Environ. Econ. Manage. 44, 23-44.

Mowery D.C., RR Nelson, BR Martin, (2010), Technology policy and global warming: Why new policy models are needed (or why putting new wine in old bottles won't work) Research Policy, Volume 39, Issue 8, October, Pages 1011-1023

Nameroff T.J., Garant J., Albert M.B., (2004), Adoption of green chemistry: an analysis based on US patents. Research Policy 33, 959-974.

Nandkumar, A., \& Srikanth, K. (2015). Right person in the right place: How the host country IPR influences the distribution of inventors in the offshored R\&D projects of multinational enterprises. Strategic Management Journal.

Nelson, R.R. and S.G. Winter (1982). An evolutionary theory of economic change. Harvard University Press, Cambridge, Mas.

Nerkar A., (2003), Old Is Gold? The Value of Temporal Exploration in the Creation of New Knowledge. Management Science. Vol. 49, No. 2, February, pp. 211-229.

Nesta L., Vona F., Nicolli F., (2012). Documents de Travail de l'OFCE 2012-25, Observatoire Francais des Conjonctures Economiques (OFCE)

Newell, R. G., Ja_e, A. B., and Stavins, R. N. (1999). The Induced Innovation Hypothesis and Energy-Saving Technological Change. The Quarterly Journal of Economics, 114(3):941-975.

OECD (2005) A Framework for biotechnology statistics, OECD, Paris.

Nill J., Kemp, R., (2009), Evolutionary approaches for sustainable innovation policies: from niche to paradigm, Research Policy. 38. pp 668-680.

Oltra, V., Kemp, R., \& De Vries, F. P. (2010). Patents as a measure for eco-innovation. International Journal of Environmental Technology and Management, 13(2), 130-148.

Patel, P. and K. Pavitt (1991). "Large Firms in the Production of the Worlds Technology- an Important Case of Non-Globalization." Journal of International Business Studies 22(1): 1-21.

Pernick, R., Wilder C (2007). The Clean technologies Revolution: The Next Big Growth and Investment Opportunity. Collins.

Peters, M., Schneider, M., Griesshaber, T., Hoffmann, V.H., (2012). The impact of technologypush and demand-pull policies on technical change - does the locus of policies matter? Research Policy 41 (8), 1296-1308. 
Piscitello L., Garrone P., Wang Y. (2012), Cross-country spillovers in the renewable energy sector. DRUID 2012 June, 23 pages.

Popp D., I. Hascic, N. Medhi (2011)Technology and the diffusion of renewable energy. Energy Economics. Volume 33, Issue 4, July 2011, Pages 648-662

Popp, D. (2002). Induced Innovation and Energy Prices. The American Economic Review, 92(1):160-180.

Porter, M. E. and Van Der Linde, C., (1995), «Toward a new conception of the environmentcompetitiveness relationship », Journal of Economic Perspectives, vol. 9, $n^{\circ}$ 4, p. 97-118.

Pottier A., J. C. Hourcade, Etienne Espagne, (2014), Modelling the redirection of technical change : The pitfalls of incorporeal visions of the economy, Energy Economics, Volume 42, March, Pages 213-218.

Poussing N., Le Bas C. (2013), Firm voluntary measures for environmental changes, eco-innovations and CSR: Empirical analysis based on data surveys. Economie Appliquée $\mathrm{N}^{\circ} 4$ décembre, pp141166.

Rassenfosse, G., Dernis, H., Guellec, D., Picci, L., van Pottelsberghe de la Potterie, B., (2013),. The worldwide count of priority patents: a new indicator of inventive activity. Research Policy 42, 720 737.

Rehfeld, K.-M., Rennings, K., Ziegler, A., (2007). Integrated product policy and environmental product innovations: an empirical analysis. Ecological Economics 1, 91-100.

Rennings K., (2000). "Redefining innovation -- eco-innovation research and the contribution from ecological economics," Ecological Economics, Elsevier, vol. 32(2), pages 319-332, February.

Requate T., (2005), Dynamic incentives by environmental policy instruments - a survey, Ecolog. Econ. 54. 175-195.

Scott J.T., (1997), Schumpeterian competition and environmental R\&D, Managerial Decision Econom. 18. 455-469.

Simpson R. D. and Bradford R. L., (1996), "Taxing Variable Cost: Environmental regulation as Industrial Policy" Journal of Environmental Economics and Management vol. 30, pp. 282-300.

Sinn, H.-W. (2008), "Public Policies Against Global Warming: A Supply Side Approach", International Tax and Public Finance, 15: 360-394.

Stucki T. and Woerter M., (2012), Determinants of Green Innovation: The Impact of Internal and External Knowledge. KOF Working Papers $n^{\circ} 314$. Sept.

Taylor A, Greve HR. 2006. Superman or the Fantastic Four? Knowledge combination and experience in innovative teams. Academy of Management Journal 49(4): 723-740.

Teece D. J. (2007). Explicating dynamic capabilities: The nature and microfoundations of (sustainable) enterprise performance. Strategic Management Journal 28(13): 1319-1350.

Unruh, G.C. (2000). Understanding carbon lock-in. Energy policy, 28(12), 817-830.

Veefkind V. Hurtado-Albir J.Author Vitae, Angelucci S.Author Vitae, Karachalios K.Author Vitae, Thumm N., (2012): «A new EPO classification scheme for climate change mitigation technologies », World Patent Information, 34(2),106-111.

Verdolini, D., Galeotti, M., (2011), At home and abroad: an empirical analysis of innovation and diffusion in energy technologies, Journal of Environmental Economics and Management, 61(2), 119-134.

Verdolini, E., Galeotti, M., 2011. At home and abroad: an empirical analysis of innovation and diffusion in energy technologies. J. Environ. Econ. Manag. 61 (2), 119-134.

Veugelers R. (2012), Which policy instruments to induce clean innovating? Research Policy, 41, $1770-1778$.

Veugelers, R. (2012). Which policy instruments to induce clean innovating?. Research Policy, 41(10), 1770-1778.

Vezzani A, Montobbio F, Montresor F, Tarasconi G, (2014) The patenting activity of the top IRI Scoreboard Companies: an introductory note. JRC Report, Publications Office, European Commission 2014.

Wagner M. et Llerena P., (2011). "Eco-innovation through integration, regulation and cooperation: comparative insights from case studies in three manufacturing sectors", Industry and Innovation, vol. 18, p. 747-764. 
Wagner M., (2007). "The Link between Environmental Innovation, Patents, and Environmental Management", DRUID Working Papers, n ${ }^{\circ}$ 07-14.

Wagner, M. 2003. The Porter Hypothesis Revisited: A Literature Review of Theoretical

Wagner, M., (2008). Empirical influence of environmental management on innovation: evidence from Europe. Ecological Economics 66, 392-402.

Wagner, M., 2008. Empirical influence of environmental management on innovation: evidence from Europe. Ecol. Econ. 6, 392-402.

Williamson D, Lynch-Wood G, Ramsay J, (2006), "Drivers of environmental behaviour in manufacturing SMEs and the implications for CSR" Journal of Business Ethics 67 (3) 317-330

Worthington I, Patton D, (2005), "Strategic intent in the management of the green environment within SMEs: an analysis of the UK screen-printing sector" Long Range Planning 38 (2) 197-212.

Zahra S, George G. 2002. Absorptive capacity: a review, reconceptualization, and extension. Academy of Management Review 27(2): 185-203.

Ziegler, A. (2013) 'Disentangling technological innovations: A micro-econometric analysis of their determinants', Journal of Environmental Planning and Management [online].http://www.tandfonline.com/doi/abs/10.1080/09640568.2013.855180\#.VClKoEDuBf8 (Accessed 29 September 2014).

Ziegler, A. and Nogareda, J. S., (2009), «Environmental management systems and technological environmental innovations: Exploring the causal relationship », Research Policy, vol. $38, \mathrm{n}^{\circ}$ 5, p. 885-893. 


\begin{tabular}{|c|c|c|c|c|c|c|}
\hline Variables & $\begin{array}{c}\text { All } \\
\text { Mean }\end{array}$ & $\begin{array}{l}\mathrm{N}=946 \\
\text { S.D. }\end{array}$ & $\begin{array}{c}\text { With Clean technologies } \\
\text { Mean }\end{array}$ & $\begin{array}{l}\mathrm{N}=431 \\
\text { S.D. }\end{array}$ & $\begin{array}{c}\text { Dirty technologies Only } \\
\text { Mean }\end{array}$ & $\begin{array}{l}\mathrm{N}=515 \\
\text { S.D. }\end{array}$ \\
\hline \multicolumn{7}{|l|}{ EXPLAINED VARIABLES } \\
\hline $\begin{array}{l}\text { Number of Clean Patents } \\
(2003-2005)\end{array}$ & 21,45 & 108,95 & 47,09 & 157,72 & 0 & 0 \\
\hline $\begin{array}{l}\text { Number of Dirty Patents } \\
(2003-2005)\end{array}$ & 911,88 & 3503,07 & 1865,27 & 5022,24 & 113,99 & 245,97 \\
\hline \multicolumn{7}{|l|}{ EXPLANATORY } \\
\hline \multicolumn{7}{|l|}{ VARIABLES } \\
\hline \multicolumn{7}{|l|}{ Firm level } \\
\hline $\begin{array}{l}\text { Own Stock } \\
\text { Patents }\left(\log \mathrm{K}^{\mathrm{C}}\right)\end{array}$ & $-1,73$ & 4,50 & 1,67 & 3,25 & $-4,58$ & 3,26 \\
\hline $\begin{array}{l}\text { No previous Clean } \\
\text { Patent }\end{array}$ & 0,39 & 0,49 & 0,09 & 0,28 & 0,65 & 0,48 \\
\hline $\begin{array}{l}\text { Own Stock Dirty Patents } \\
\left(\log K^{D}\right)\end{array}$ & 5,56 & 1,82 & 6,71 & 1,74 & 4,61 & 1,25 \\
\hline $\begin{array}{l}\text { Clean Spillovers (log } \\
\left.\text { SPILL }^{\mathrm{C}}\right)\end{array}$ & 9,47 & 1,01 & 9,62 & 0,88 & 9,33 & 1,09 \\
\hline $\begin{array}{l}\text { Dirty Spillovers }(\log \\
\left.\text { SPILL }^{\text {D }}\right)\end{array}$ & 13,53 & 0,90 & 13,63 & 0,74 & 13,45 & 1,00 \\
\hline Low Tech & 0,13 & 0,33 & 0,11 & 0,31 & 0,14 & 0,35 \\
\hline Medium-Low Tech & 0,06 & 0,24 & 0,08 & 0,27 & 0,05 & 0,22 \\
\hline Medium-High Tech & 0,30 & 0,46 & 0,38 & 0,49 & 0,23 & 0,42 \\
\hline High Tech & 0,32 & 0,47 & 0,26 & 0,44 & 0,37 & 0,48 \\
\hline KIB Services & 0,15 & 0,36 & 0,13 & 0,34 & 0,16 & 0,37 \\
\hline Non KIB Services & 0,04 & 0,19 & 0,03 & 0,18 & 0,04 & 0,20 \\
\hline Energy Sectors & 0,15 & 0,36 & 0,22 & 0,42 & 0,09 & 0,28 \\
\hline \multicolumn{7}{|l|}{ National level } \\
\hline GDP (log) & 28,63 & 1,37 & 28,62 & 1,24 & 28,63 & 1,47 \\
\hline GDP per capita (log) & 10,44 & 0,48 & 10,40 & 0,52 & 10,48 & 0,43 \\
\hline EU country & 0,37 & 0,48 & 0,30 & 0,46 & 0,43 & 0,50 \\
\hline
\end{tabular}

\section{Appendix 1. Descriptive Statistics}

When stock values are 0 , the value 0.001 is added to compute the log.

For manufacturing firms: HT is set to 1 if the firm belongs to the 244,300,321-323,331-335 and 353 industries from the NACE classification (rev 1). MH is set to 1 if the firm belongs to the 241-243, 245-247, 291-297, 311-316, 341-343, 352 and 354-355 industries in the NACE classification (rev 1). ML is set to 1 if the firm belongs to the 231-233, 251, 252, 261-268, 271-275, 281-287, and 351 industries in the NACE classification (rev 1). LT is set to 1 if the firm belongs to the 151-159, 160, 171-177, 181-183, 191-193, 200-209, 210-219, 220-229, 361-366, 371, and 372 industries in the NACE classification (rev 1.1). For service firms, the codification is the following: KIS is set to 1 if the firm belongs to the 40,41, 61, 62, 64-67, 70-74, 80, 85 and 92 industries in the NACE classification (rev 1). LKIS is set to 1 if the firm belongs to other services. 
Table 1. Distribution of firms, clean inventions and patenting, by firm countries

\begin{tabular}{lccc}
\hline Country of firms & $\begin{array}{c}\text { Firm share } \\
(\%)\end{array}$ & $\begin{array}{c}\text { Share of clean } \\
\text { patents }(\%)\end{array}$ & $\begin{array}{c}\text { Share of all } \\
\text { patents }(\%)\end{array}$ \\
\hline North America & 35.2 & 6.0 & 11.8 \\
$\quad$ United States & 34.0 & 5.7 & 11.5 \\
Europe & 36.9 & 6.9 & 10.2 \\
$\quad$ Germany & 9.2 & 3.9 & 5.9 \\
$\quad$ United Kingdom & 6.2 & 0.2 & 0.5 \\
France & 5.3 & 1.8 & 1.6 \\
Italy & 1.2 & 0.1 & 0.1 \\
Small countries * & 7.2 & 0.6 & 1.0 \\
Nordic countries ** & 6.4 & 0.3 & 1.0 \\
Asia & 27.3 & 87.1 & 77.9 \\
$\quad$ Japan & 23.2 & 83.1 & 62.0 \\
Korea & 1.5 & 3.4 & 13.7 \\
World & 100.0 & 100.0 & 100.0 \\
\hline
\end{tabular}

*: Austria, Belgium, Netherlands, Switzerland

**: Denmark, Finland, Norway, Sweden 
Table 2: Distribution of firms, clean inventions and patenting by industry

\begin{tabular}{lccc}
\hline Industrial sectors & $\begin{array}{c}\text { Firm share } \\
(\%)\end{array}$ & $\begin{array}{c}\text { Share of clean } \\
\text { patents }(\%)\end{array}$ & $\begin{array}{c}\text { Share of all } \\
\text { patents }(\%)\end{array}$ \\
\hline Industrial Goods \& Services & 28.4 & 28.7 & 27.3 \\
Automobiles \& Parts & 9.9 & 26.2 & 14.8 \\
Personal \& Household Goods & 7.0 & 13.2 & 14.5 \\
Technology & 17.8 & 11.1 & 24.0 \\
Chemicals & 9.4 & 9.8 & 10.3 \\
Utilities & 2.3 & 3.6 & 0.7 \\
Basic Resources & 2.9 & 2.6 & 2.0 \\
Media & 0.5 & 1.5 & 1.1 \\
Construction \& Materials & 3.5 & 1.4 & 1.0 \\
Oil \& Gas & 2.7 & 1.0 & 1.0 \\
Telecommunications & 1.3 & 0.6 & 1.8 \\
Health Care & 11.3 & 0.3 & 1.3 \\
Banks & 0.6 & 0.0 & 0.0 \\
Retail & 1.0 & 0.0 & 0.1 \\
Financial Services & 0.5 & 0.0 & 0.0 \\
Insurance & 0.1 & 0.0 & 0.0 \\
Travel \& Leisure & 0.7 & 0.0 & 0.1 \\
Total & 100.0 & 100.0 & 100.0 \\
\hline
\end{tabular}


Table 3. Main Results

\begin{tabular}{|c|c|c|c|c|c|c|c|c|c|}
\hline $\begin{array}{r}\text { Column } \\
\text { Estimator }\end{array}$ & $\begin{array}{c}(1) \\
\text { Neg.Bin. }\end{array}$ & $\begin{array}{c}(2) \\
\text { Neg.Bin. }\end{array}$ & $\begin{array}{c}(3) \\
\text { Neg.Bin. }\end{array}$ & $\begin{array}{c}(4) \\
\text { Neg.Bin. }\end{array}$ & $\begin{array}{c}\text { OLS } \\
\text { OLS }\end{array}$ & $\begin{array}{l}\text { (6) } \\
\text { OLS }\end{array}$ & (7) & SURE & (9) \\
\hline Technology & Clean & Dirty & Clean & Dirty & Clean & Dirty & Clean & Dirty & Clean/Dirty \\
\hline Specificity & $15 \%$ rate & $15 \%$ rate & \multicolumn{2}{|c|}{$\begin{array}{l}\text { Clusterised s.e. } \\
\text { on country }\end{array}$} & $\log \left(\mathrm{PAT}^{\mathrm{C}}+1\right)$ & $\log \left(\mathrm{PAT}^{\mathrm{D}}+1\right)$ & $\log \left(\mathrm{PAT}^{\mathrm{C}}+1\right)$ & $\log \left(\mathrm{PAT}^{\mathrm{D}}+1\right)$ & $\begin{array}{l}\log \left(\mathrm{PAT}^{\mathrm{C}}+1\right) \\
\log \left(\mathrm{PAT}^{\mathrm{D}}+1\right) \\
\end{array}$ \\
\hline Own Stock Clean Patents $\left(\log \mathrm{K}^{\mathrm{C}}\right)$ & $0,753 * * *$ & $\begin{array}{c}0,012 \\
(0,017)\end{array}$ & $0,589 * * *$ & 0,016 & $0,589 * * *$ & $\begin{array}{c}0,016 \\
(0,017)\end{array}$ & $0,589 * * *$ & $\begin{array}{c}0,016 \\
(0,022)\end{array}$ & $0,572^{* * * *}$ \\
\hline \multirow[t]{2}{*}{ Own Stock Dirty Patents $\left(\log \mathrm{K}^{\mathrm{D}}\right)$} & $0,246 * * *$ & $0,914 * * *$ & $0,133 * * *$ & $0,932 * * *$ & $0,133 * * *$ & $0,932 * * *$ & $0,133 * * *$ & $0,932 * * *$ & $-0,800 * * *$ \\
\hline & $(0,038)$ & $(0,018)$ & $(0,021)$ & $(0,020)$ & $(0,019)$ & $(0,019)$ & $(0,014)$ & $(0,027)$ & $(0,023)$ \\
\hline \multirow[t]{2}{*}{ Clean Spillovers $\left(\log\right.$ SPILL $^{\mathrm{C}}$ ) } & $0,547 * *$ & 0,066 & $0,318^{* *}$ & $-0,022$ & $0,318 * *$ & $-0,022$ & 0,318 & $-0,022$ & $0,339 * *$ \\
\hline & $(0,233)$ & $(0,125)$ & $(0,143)$ & $(0,130)$ & $(0,128)$ & $(0,128)$ & $(0,234)$ & $(0,255)$ & $(0,150)$ \\
\hline \multirow[t]{2}{*}{ Dirty Spillovers $\left(\log\right.$ SPILL $^{\mathrm{D}}$ ) } & $-0,629 * *$ & $-0,167$ & $-0,355 * *$ & $-0,016$ & $-0,355 * *$ & $-0,016$ & $-0,355$ & $-0,016$ & $-0,339 * *$ \\
\hline & $(0,275)$ & $(0,141)$ & $(0,156)$ & $(0,147)$ & $(0,143)$ & $(0,143)$ & $(0,246)$ & $(0,275)$ & $(0,167)$ \\
\hline \multirow[t]{2}{*}{ GDP $(\log )$} & $-0,093^{*}$ & $-0,109^{* * *}$ & $-0,028$ & $-0,049^{*}$ & $-0,028$ & $-0,049^{* *}$ & $-0,028$ & $-0,049$ & 0,021 \\
\hline & $(0,054)$ & $(0,024)$ & $(0,026)$ & $(0,030)$ & $(0,025)$ & $(0,025)$ & $(0,027)$ & $(0,053)$ & $(0,029)$ \\
\hline \multirow[t]{2}{*}{ GDP per capita (log) } & $-0,331 * * *$ & $-0,164 * * *$ & $-0,103^{* *}$ & $-0,127^{*}$ & $-0,103 * *$ & $-0,127^{* *}$ & $-0,103$ & $-0,127$ & 0,023 \\
\hline & $(0,102)$ & $(0,058)$ & $(0,051)$ & $(0,071)$ & $(0,052)$ & $(0,052)$ & $(0,079)$ & $(0,131)$ & $(0,061)$ \\
\hline \multirow[t]{2}{*}{ EU country } & 0,018 & $-0,159 * *$ & 0,002 & 0,011 & 0,002 & 0,011 & 0,002 & 0,011 & $-0,010$ \\
\hline & $(0,143)$ & $(0,067)$ & $(0,075)$ & $(0,080)$ & $(0,071)$ & $(0,071)$ & $(0,075)$ & $(0,154)$ & $(0,084)$ \\
\hline \multirow[t]{2}{*}{ Medium-Low Tech } & 0,074 & $-0,135$ & 0,111 & $-0,106$ & 0,111 & $-0,106$ & 0,111 & $-0,106$ & $0,217^{*}$ \\
\hline & $(0,203)$ & $(0,106)$ & $(0,111)$ & $(0,100)$ & $(0,107)$ & $(0,107)$ & $(0,075)$ & $(0,117)$ & $(0,126)$ \\
\hline \multirow[t]{2}{*}{ Medium-High Tech } & $0,338^{* *}$ & 0,015 & 0,215 *** & 0,040 & $0,215 * * *$ & 0,040 & $0,215^{* * * *}$ & 0,040 & $0,175^{* *}$ \\
\hline & $(0,148)$ & $(0,073)$ & $(0,076)$ & $(0,071)$ & $(0,074)$ & $(0,074)$ & $(0,072)$ & $(0,095)$ & $(0,087)$ \\
\hline \multirow[t]{2}{*}{ High Tech } & 0,002 & $0,239 * * *$ & 0,052 & $0,148^{* * *}$ & 0,052 & $0,148 * *$ & 0,052 & $0,148^{* *}$ & $-0,096$ \\
\hline & $(0,161)$ & $(0,073)$ & $(0,074)$ & $(0,073)$ & $(0,075)$ & $(0,075)$ & $(0,064)$ & $(0,065)$ & $(0,087)$ \\
\hline \multirow[t]{2}{*}{ KIB Services } & $0,333^{*}$ & 0,110 & $0,161^{* *}$ & $-0,033$ & $0,161 *$ & $-0,033$ & $0,161 * * *$ & $-0,033$ & $0,194 * *$ \\
\hline & $(0,175)$ & $(0,083)$ & $(0,081)$ & $(0,087)$ & $(0,084)$ & $(0,084)$ & $(0,061)$ & $(0,073)$ & $(0,099)$ \\
\hline \multirow[t]{2}{*}{ Non KIB Services } & $-0,099$ & $-0,009$ & 0,076 & 0,056 & 0,076 & 0,056 & 0,076 & 0,056 & 0,019 \\
\hline & $(0,269)$ & $(0,127)$ & $(0,110)$ & $(0,100)$ & $(0,127)$ & $(0,127)$ & $(0,113)$ & $(0,125)$ & $(0,149)$ \\
\hline \multirow[t]{2}{*}{ Energy sectors } & $0,314 * * *$ & $0,299 * * *$ & $0,149^{* *}$ & $0,217 * * *$ & $0,149 * *$ & $0,217 * * *$ & $0,149 * * *$ & $0,217 * * *$ & $-0,067$ \\
\hline & $(0,114)$ & $(0,065)$ & $(0,074)$ & $(0,067)$ & $(0,066)$ & $(0,066)$ & $(0,051)$ & $(0,050)$ & $(0,077)$ \\
\hline \multirow[t]{2}{*}{ Intercept } & $7,835 * * *$ & $6,360 * * *$ & $3,375 * * *$ & $2,729 * *$ & $3,375^{* * * *}$ & $2,729 * * *$ & $3,375^{* * *}$ & 2,729 & 0,646 \\
\hline & $(2,114)$ & $(1,040)$ & $(1,032)$ & $(1,274)$ & $(0,996)$ & $(0,996)$ & $(1,484)$ & $(1,912)$ & $(1,167)$ \\
\hline Log-Likelihood & $-1724,82$ & $-5606,04$ & $-953,49$ & $-1858,22$ & $-953,34$ & $-953,34$ & \multirow{2}{*}{\multicolumn{2}{|c|}{$\begin{array}{c}-1104,04 \\
114,154\end{array}$}} & $-953,49$ \\
\hline chi2 & 1276,912 & 2392,397 & 4539,804 & 10021,125 & 293,617 & 1600,782 & & & 443,199 \\
\hline
\end{tabular}

Notes: ***,*** significant at $10 \%, 5 \%$ and $1 \%$ levels. The number of observations is 946 . The explained variables in Columns (1) and (2) is the number of patents filed on the $2003-2005$ period, rounded to the upper number. The depreciation rate is $15 \%$ in all the columns. Country level variables: GDP, GDP per capita are 2002 variables. Industry level: 3 industry dummies according to the technological level (OECD classification extended to services), KIBS and non-KIKBS dummies as well asan energy dummy. Low Tech industries are taken as a reference. A dummy is introduced when the weighted stocks of patents are null (not reported). A negative binomial model is implemented because overdispersion is found significant in every count model. In columns (3) and (4), standard errors are clustered on country names to take account of unobserved national policies likely to influence the strategies of firms belonging to the same country. In Column (9) we have the difference of logarithms or, in other words, the relative importance of green patents compared to dirty patents. Rho is the correlation among residuals in the SURE model (Col. 7 and 8) showing a complementarity of dirty and clean patenting strategies. 
Table 4. Comparing estimated elasticities (rate of depreciation: $15 \%$ )

\begin{tabular}{lcc}
\hline & Clean patents & "Dirty" patents \\
\hline Internal or own & $0.3 *$ & $0.0^{*}$ \\
stock of clean patents & 0.4 to $0.7 * *$ & \\
& $0.6^{* * *}$ & $0.0^{* * *}$ \\
\hline Internal or own & $0.14^{*}$ & $0.55^{*}$ \\
stock of dirty ( = not clean) patents & 0 to $0.2^{* *}$ & - \\
& $0.13^{* * *}$ & $0.9^{* * *}$ \\
\hline * Aghion et al. (2015) firms in energy sector, & \\
** Stucki and Woerter (2012) industry level, & \\
$* * *$ Our own research firm level (worldwide largest R\&D investors) &
\end{tabular}


Table 5: Robustness tests

\begin{tabular}{|c|c|c|c|c|c|c|c|c|}
\hline & \multirow{2}{*}{\multicolumn{2}{|c|}{$\begin{array}{l}(1) \quad(2) \\
\text { No Energy Sector }\end{array}$}} & \multirow{2}{*}{\multicolumn{2}{|c|}{$\begin{array}{l}\text { (3) } \\
\text { No Asian Country }\end{array}$}} & \multirow{2}{*}{\multicolumn{2}{|c|}{$\begin{array}{l}(5) \\
\text { No Small countries }\end{array}$}} & \multirow{2}{*}{\multicolumn{2}{|c|}{$\begin{array}{c}(7) \\
\text { Control for productivity }\end{array}$}} \\
\hline & & & & & & & & \\
\hline & Clean & Dirty & Clean & Dirty & Clean & Dirty & Clean & Dirty \\
\hline Own Stock Clean Patents $\left(\log \mathrm{K}^{\mathrm{C}}\right)$ & $0,726 * * *$ & 0,024 & 0,731 *** & 0,024 & $0,757 * * *$ & 0,015 & $0,775 * * *$ & 0,018 \\
\hline & $(0,037)$ & $(0,020)$ & $(0,048)$ & $(0,024)$ & $(0,032)$ & $(0,018)$ & $(0,037)$ & $(0,019)$ \\
\hline Own Stock Dirty Patents $\left(\log K^{\mathrm{D}}\right)$ & $\begin{array}{c}0,271 * * * \\
(0,045)\end{array}$ & $\begin{array}{c}0,904 * * * \\
(0,020)\end{array}$ & $\begin{array}{c}0,245^{* * * *} \\
(0,055)\end{array}$ & $\begin{array}{c}0,902 * * * \\
(0,023)\end{array}$ & $\begin{array}{c}0,241^{* * * *} \\
(0,039)\end{array}$ & $\begin{array}{c}0,908 * * * \\
(0,019)\end{array}$ & $\begin{array}{c}0,191 * * * \\
(0,046)\end{array}$ & $\begin{array}{c}0,881 * * * \\
(0,022)\end{array}$ \\
\hline Clean Spillovers $\left(\log\right.$ SPILL $\left.^{\mathrm{C}}\right)$ & $\begin{array}{l}0,515^{*} \\
(0,269)\end{array}$ & 0,016 & $1,304 *$ & $\begin{array}{c}1,264 * * * \\
(0.280)\end{array}$ & $\begin{array}{c}0,507 * * \\
(0,240)\end{array}$ & $\begin{array}{c}0,101 \\
(0,128)\end{array}$ & $\begin{array}{c}0,899 * * * \\
(0,307)\end{array}$ & $0,408 * *$ \\
\hline Dirty Spillovers $\left(\log\right.$ SPILL $\left.^{\mathrm{D}}\right)$ & $\begin{array}{c}-0,529 * \\
(0,319)\end{array}$ & $\begin{array}{l}-0,122 \\
(0,156)\end{array}$ & $\begin{array}{c}-1,403^{*} \\
(0,746)\end{array}$ & $\begin{array}{c}-1,382 * * * \\
(0,295)\end{array}$ & $\begin{array}{c}0,240) \\
-0,566^{*} \\
(0,289)\end{array}$ & $\begin{array}{c}0,120) \\
-0,255^{*} \\
(0,147)\end{array}$ & $\begin{array}{c}-0,971 * * * \\
(0,361)\end{array}$ & $\begin{array}{c}(0,573 * * * \\
(0,189)\end{array}$ \\
\hline Productivity $(\log )$ & & & & & & & $\begin{array}{c}0,041 \\
(0,105)\end{array}$ & $\begin{array}{c}0,005 \\
(0,049)\end{array}$ \\
\hline GDP $(\log )$ & $\begin{array}{l}-0,091 \\
(0,061)\end{array}$ & $\begin{array}{c}-0,102 * * * \\
(0,026)\end{array}$ & $\begin{array}{c}0,037 \\
(0,076)\end{array}$ & $\begin{array}{l}-0,032 \\
(0,029)\end{array}$ & $\begin{array}{c}-0,137 * * \\
(0,063)\end{array}$ & $\begin{array}{c}-0,179 * * * \\
(0,029)\end{array}$ & $\begin{array}{l}-0,047 \\
(0,082)\end{array}$ & $\begin{array}{c}-0,138 * * * \\
(0,036)\end{array}$ \\
\hline GDP per capita (log) & $\begin{array}{c}-0,431 * * * \\
(0,128)\end{array}$ & $\begin{array}{c}-0,246 * * * \\
(0,068)\end{array}$ & $\begin{array}{l}-0,079 \\
(0,127)\end{array}$ & $\begin{array}{c}0,091 \\
(0,059)\end{array}$ & $\begin{array}{c}-0,376^{* * *} * \\
(0,119)\end{array}$ & $\begin{array}{l}-0,096 \\
(0,063)\end{array}$ & $\begin{array}{c}-0,442 * * \\
(0,219)\end{array}$ & $\begin{array}{l}-0,031 \\
(0,117)\end{array}$ \\
\hline EU country & $\begin{array}{c}0,038 \\
(0,169)\end{array}$ & $\begin{array}{c}-0,123^{*} \\
(0,074)\end{array}$ & $\begin{array}{c}0,335 \\
(0,233)\end{array}$ & $\begin{array}{l}-0,141 \\
(0,091)\end{array}$ & $\begin{array}{l}-0,028 \\
(0,150)\end{array}$ & $\begin{array}{c}-0,242 * * * \\
(0,072)\end{array}$ & $\begin{array}{c}0,163 \\
(0,189)\end{array}$ & $\begin{array}{c}-0,254 * * * \\
(0,085)\end{array}$ \\
\hline Medium-Low Tech & $\begin{array}{c}0,077 \\
(0,235)\end{array}$ & $\begin{array}{c}-0,280 * * \\
(0,115)\end{array}$ & $\begin{array}{l}-0,026 \\
(0,325)\end{array}$ & $\begin{array}{c}0,026 \\
(0,130)\end{array}$ & $\begin{array}{c}0,046 \\
(0,209)\end{array}$ & $\begin{array}{l}-0,134 \\
(0,110)\end{array}$ & $\begin{array}{c}0,105 \\
(0,239)\end{array}$ & $\begin{array}{l}-0,048 \\
(0,122)\end{array}$ \\
\hline Medium-High Tech & $\begin{array}{c}0,393 * * \\
(0,181)\end{array}$ & $\begin{array}{l}-0,093 \\
(0,082)\end{array}$ & $\begin{array}{c}0,097 \\
(0,219)\end{array}$ & $\begin{array}{c}0,040 \\
(0,087)\end{array}$ & $\begin{array}{c}0,352 * * \\
(0,152)\end{array}$ & $\begin{array}{l}-0,024 \\
(0,075)\end{array}$ & $\begin{array}{l}0,316^{*} \\
(0,182)\end{array}$ & $\begin{array}{l}-0,062 \\
(0,086)\end{array}$ \\
\hline High Tech & $\begin{array}{l}-0,003 \\
(0,183)\end{array}$ & $\begin{array}{l}0,161 * * \\
(0,078)\end{array}$ & $\begin{array}{l}-0,111 \\
(0,233)\end{array}$ & $\begin{array}{c}0,257 * * * * \\
(0,085)\end{array}$ & $\begin{array}{c}0,006 \\
(0,164)\end{array}$ & $\begin{array}{c}0,214 * * * \\
(0,075)\end{array}$ & $\begin{array}{c}0,141 \\
(0,194)\end{array}$ & $\begin{array}{c}0,269 * * * \\
(0,087)\end{array}$ \\
\hline KIB Services & $\begin{array}{c}0,241 \\
(0,217)\end{array}$ & $\begin{array}{c}0,017 \\
(0,092)\end{array}$ & $\begin{array}{c}0,063 \\
(0,249)\end{array}$ & $\begin{array}{c}0,076 \\
(0,094)\end{array}$ & $\begin{array}{c}0,352 * * \\
(0,179)\end{array}$ & $\begin{array}{c}0,096 \\
(0,084)\end{array}$ & $\begin{array}{l}0,369 * \\
(0,210)\end{array}$ & $\begin{array}{c}0,127 \\
(0,098)\end{array}$ \\
\hline Non KIB Services & $\begin{array}{l}-0,072 \\
(0,285)\end{array}$ & $\begin{array}{l}-0,098 \\
(0,131)\end{array}$ & $\begin{array}{l}-0,421 \\
(0,391)\end{array}$ & $\begin{array}{c}0,052 \\
(0,143)\end{array}$ & $\begin{array}{l}-0,080 \\
(0,272)\end{array}$ & $\begin{array}{l}-0,013 \\
(0,129)\end{array}$ & $\begin{array}{l}-0,071 \\
(0,292)\end{array}$ & $\begin{array}{c}0,001 \\
(0,139)\end{array}$ \\
\hline Energy Sectors & & & $\begin{array}{c}0,260 \\
(0,173)\end{array}$ & $\begin{array}{c}0,189 * * \\
(0,081)\end{array}$ & $\begin{array}{c}0,309 * * * \\
(0,115)\end{array}$ & $\begin{array}{c}0,290 * * * \\
(0,065)\end{array}$ & $\begin{array}{c}0,427 * * * \\
(0,131)\end{array}$ & $\begin{array}{c}0,416 * * * \\
(0,072)\end{array}$ \\
\hline Intercept & $\begin{array}{c}7,635^{* * * *} \\
(2,472)\end{array}$ & $\begin{array}{c}7,028^{* * *} \\
(1,134)\end{array}$ & $\begin{array}{c}4,850 \\
(3,950)\end{array}$ & $\begin{array}{c}6,693 * * * \\
(1,581)\end{array}$ & $\begin{array}{c}9,108 * * * \\
(2,289)\end{array}$ & $\begin{array}{c}8,624 * * * \\
(1,112)\end{array}$ & $\begin{array}{c}9,211 * * * \\
(2,770)\end{array}$ & $\begin{array}{c}8,310 * * * \\
(1,390)\end{array}$ \\
\hline Number of observations & 806 & 806 & 696 & 696 & 900 & 900 & 665 & 665 \\
\hline Log-Likelihood & $-1331,39$ & $-4680,90$ & $-850,41$ & $-3702,13$ & $-1676,55$ & $-5375,29$ & $-1316,27$ & $-4019,30$ \\
\hline HO: All coeff. $=0$ & 1009,930 & 2109,759 & 580,356 & 1435,184 & 1229,428 & 2292,056 & 962,554 & 1727,830 \\
\hline H0: alpha $=0$ & $\begin{array}{c}-0,248^{* *} \\
(0,108)\end{array}$ & $\begin{array}{c}-0,901 * * * \\
(0,049)\end{array}$ & $\begin{array}{l}-0,047 \\
(0,139)\end{array}$ & $\begin{array}{c}-0,868 * * * \\
(0,053)\end{array}$ & $\begin{array}{c}-0,278 * * * \\
(0,093)\end{array}$ & $\begin{array}{c}-0,892 * * * \\
(0,046)\end{array}$ & $\begin{array}{c}-0,356 * * * \\
(0,107)\end{array}$ & $\begin{array}{c}-0,982 * * * \\
(0,054)\end{array}$ \\
\hline
\end{tabular}

Notes: $* * *, * * *$ significant at $10 \%, 5 \%$ and $1 \%$ levels. The number of observations depends on filters or missing values. The explained variables in Columns (1) to (8) are the number of patents filed on the 2003-2005 period, rounded to the upper number. Stocks are computed accordingly for the 1986-2002 period. The depreciation rate is 15\%. Country level variables are: GDP, GDP per capita are 2002 variables in columns (1) to (8). Industry level: 3 industry dummies according to the technological level (OECD classification extended to services), KIBS and non-KIKBS dummies as well asan energy dummy. Low Tech industries are taken as a reference. Small countries are countries with $\log ($ GDP $)<26$. ASEAN countries are China, Taiwan, Hong-Kong, Japan, South-Korea and Singapore. Labour productivity at the firm level (in $\log$ ) is introduced in column ((7) and (8). Industry level: 4 industry dummies according to the technological level (OECD classification extended to services) and an energy dummy. A dummy is introduced when the weighted stocks of patents are null (not reported). A negative binomial model is implemented in every column. Overdispersion is assumed to betested as significant in every column. 
Figure 1: Schematic view of the CIB database building

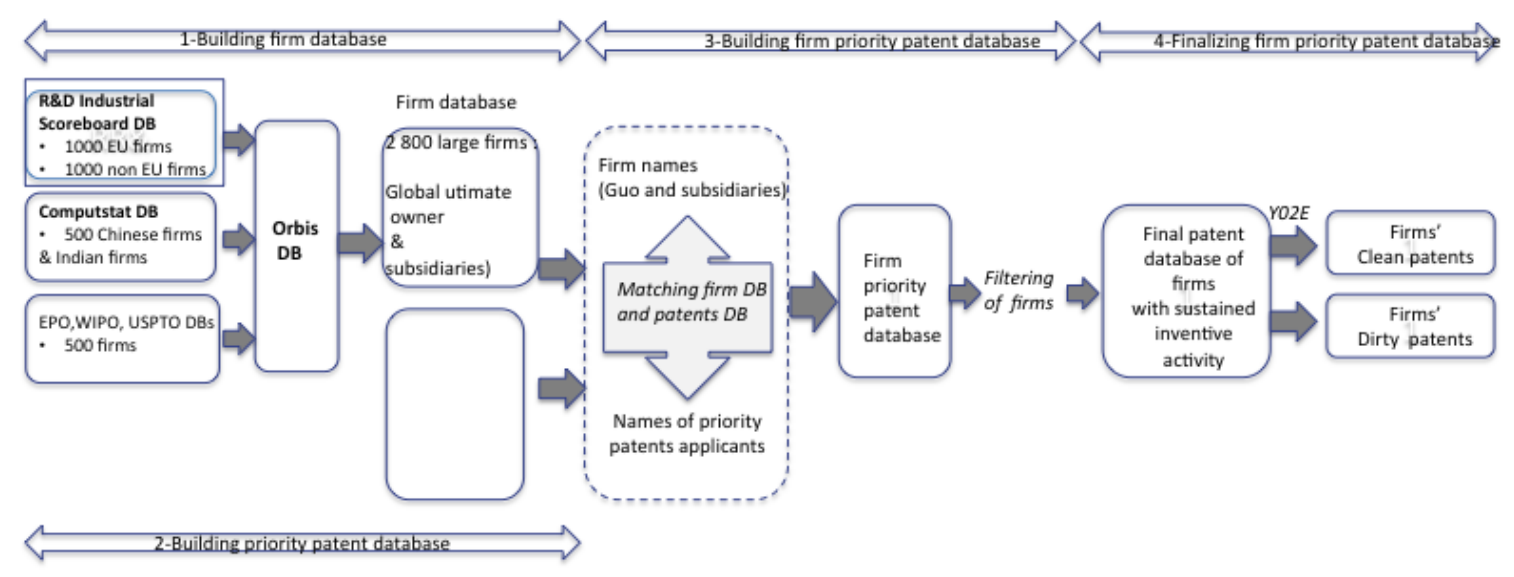

